\title{
Non-canonical amino acids bearing thiophene and bithiophene: synthesis by an Ugi multicomponent reaction and studies on ion recognition ability
}

\author{
Cátia I. C. Esteves, M. Manuela M. Raposo and Susana P. G. Costa \\ Centre of Chemistry, University of Minho, Campus de Gualtar, 4710-057 Braga, Portugal
}

\begin{abstract}
Novel thienyl and bithienyl amino acids with different substituents were obtained by a multicomponent Ugi reaction between a heterocyclic aldehyde, an amine, an acid and an isocyanide. Due to the presence of the sulphur heterocycle at the side chain, these unnatural amino acids are highly emissive and bear extra electron donating atoms so they were tested for their ability to act as fluorescent probes and chemosensors in the recognition of biomedically relevant ions in acetonitrile and acetonitrile/water solutions. The results obtained from spectrophotometric/spectrofluorimeric titrations in the presence of organic and inorganic anions, and alkaline, alkaline-earth and transition metal cations indicated that the bithienyl amino acid bearing a methoxy group is a selective colorimetric chemosensor for $\mathrm{Cu}^{2+}$, while the other (bi)thienyl amino acids act as fluorimetric chemosensors with high sensitivity towards $\mathrm{Fe}^{3+}$ and $\mathrm{Cu}^{2+}$ in a metal-ligand complex with 1:2 stoichiometry. The photophysical and ion sensing properties of these amino acids confirm their potential as fluorescent probes suitable for incorporation into peptidic frameworks with chemosensory ability.
\end{abstract}

\section{Introduction}

Non-canonical amino acids of synthetic origin are useful for the preparation of functional peptides with tailored properties for varied applications such as increased fluorescence, conformational rigidity, and metal complexation ability, among other properties. Recent reports include the application of such amino acids in studies of molecular flexibility and protein folding, substrate binding activity of proteins, antigenicity or enzymatic activity, targeting peptides for molecular imaging, peptidomimetics biological activity and protein engineering (Kajihara et al. 2006; Hennig et al. 2007; Katritzki and Narindoshvili 2009; Lee et al. 2010; Wang et al 2012; Pless and Ahern 2013; Niu and Guo, 2013; Liu et al. 2015, Zhou et al 2016).

Many biochemical processes rely on the coordinating ability that amino acids and peptides display towards metal ions because they possess electron donor atoms like nitrogen, oxygen and sulphur at 
the main and side chains (Zheng et al. 2003; Shimazaki et al. 2009). Therefore, the insertion of suitable heterocycles at the side chain of natural amino acids, along increasing the number of binding sites, can provide increased UV absorption and fluorescence, which can be valuable for biochemistry, cellular biology and cellular imaging applications. Fluorescent probes are indispensable tools for monitoring ions and biomolecules with high sensitivity in cells and tissues, as they present distinct advantages in fluorescence detection in terms of sensitivity, selectivity, response time and local observation, etc. There are various examples of fluorescent unnatural amino acids, displaying better photophysical properties than tryptophan, that have been inserted in peptide and protein frameworks in order to afford fluorescently labelled entities (Katritzki and Narindoshvili 2009; Cheruku et al. 2015).

Thiophene and its derivatives exhibit interesting optical properties that have led to their application as sensors and fluorescent reporters (Capobianco et al. 2012). Oligomers of thiophene present improved luminescent properties are more readily soluble in organic solvents, improves absorption efficiency and thermal stability of the resultant molecule without reducing fluorescence (Pina et al. 2010).

Selective recognition of anions is also a very dynamic topic due to their importance in medicinal and environmental areas. Especially, the development of colorimetric and fluorimetric chemosensors for anions has been widely investigated due to the relevance of several anions in biological processes (Veale and Gunnlaugsson 2010; Moragues et al. 2011; Santos-Figueroa et al. 2013).

Bearing the above facts in mind, there is a practical interest on the design of unnatural amino acids and our research group has been engaged on the synthesis of heterocyclic amino acids and their application as fluorescent markers and fluorimetric probes for metal ions (Batista et al. 2012; Costa et al. 2007, 2008a, 2008b; Esteves et al. 2009, 2010, 2011, 2016; Oliveira et al. 2011). We now report the synthesis and characterization of novel non-canonical amino acids bearing thiophene and bithiophene moieties, by an Ugi multicomponent reaction between a heterocyclic aldehyde, an amine, an acid and an isocyanide. This reaction is a straightforward method for the synthesis of $\alpha$ and $\alpha, \alpha$-substituted glycines that allows the introduction of a variety of groups and functionalities at the side chain (Dömling 2006). The thiophene coordinating/reporting unit was linked with different substituents to tune the photophysical properties of the new probes and optimize the recognition of target analytes through greater fluorescence sensitivity. The recognition ability of these noncanonical amino acids toward different ions of analytical and biological relevance was evaluated by UV-vis absorption and fluorescence spectroscopy. Spectrophotometric and spectrofluorimetric titrations were made to assess their potential to act as fluorescent probes suitable for incorporation into peptidic frameworks with chemosensory ability. 


\section{Experimental Section}

\section{General}

All melting points were measured on a Stuart SMP3 melting point apparatus. TLC analyses were carried out on $0.25 \mathrm{~mm}$ thick precoated silica plates (Merck Fertigplatten Kieselgel $60 \mathrm{~F}_{254}$ ) and spots were visualised under UV light. Chromatography on silica gel was carried out on Merck Kieselgel (230-240 mesh). IR spectra were determined on a BOMEM MB 104 spectrophotometer. NMR spectra were obtained on a Varian Unity Plus Spectrometer at an operating frequency of $300 \mathrm{MHz}$ for ${ }^{1} \mathrm{H}$ and $75.4 \mathrm{MHz}$ for ${ }^{13} \mathrm{C}$ or a Bruker Avance III 400 at an operating frequency of $400 \mathrm{MHz}$ for ${ }^{1} \mathrm{H}$ and $100.6 \mathrm{MHz}$ for ${ }^{13} \mathrm{C}$ using the solvent peak as internal reference at $25{ }^{\circ} \mathrm{C}$. All chemical shifts are given in ppm using tetramethylsilane as reference and $J$ values are given in Hz. Assignments were supported by spin decoupling-double resonance and bidimensional heteronuclear correlation techniques. Low and high resolution mass spectrometry analyses were performed at the "C.A.C.T.I. - Unidad de Espectrometria de Masas", at University of Vigo, Spain. Fluorescence spectra were collected using a FluoroMax-4 spectrofluorometer. UV-visible absorption spectra $(200-600 \mathrm{~nm})$ were obtained using a Shimadzu UV/2501PC spectrophotometer. All reagents were commercially available and used as received.

\section{General procedure for the synthesis of thienyl amino acid derivatives 2a-j by an Ugi multicomponent reaction}

The appropriate aldehyde 1a-j (1 equiv) and 4-methoxybenzylamine ( 1 equiv) were dissolved in dry methanol $\left(5 \mathrm{~mL} / \mathrm{mmol}\right.$ of aldehyde) and stirred for 1 hour at $50{ }^{\circ} \mathrm{C}$, to form the corresponding imine. Acetic acid (1 equiv) was added to the previous mixture and stirred for 15 minutes at room temperature. Then, cyclohexyl isocyanide was added (1 equiv) and the mixture was left stirring at room temperature for $24 \mathrm{~h}$. The solvent was evaporated and the crude was chromatographed through a silica gel column with dichloromethane-hexane (2:1) (to elute any unreacted isocyanide), followed by dichloromethane (to elute any unreacted aldehyde) and dichloromethane-methanol (90:1) (to elute the desired product). The fractions containing the product were evaporated to dryness in a rotary evaporator.

The synthetic details and characterization for compounds $\mathbf{2 a}$ and $\mathbf{2 h}$, considered as models for the thienyl and bithienyl set of amino acids, respectively, are given below. The synthetic details and

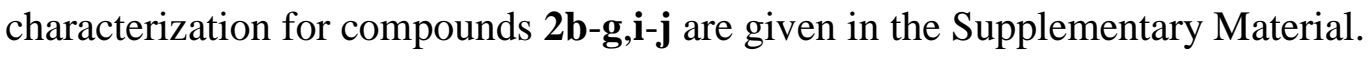


$\mathrm{N}$-Cyclohexyl-2-(N-(4'-methoxybenzyl)acetamido)-2-(thiophen-2-yl)acetamide 2a. Starting from 2-formylthiophene $1 \mathrm{a}\left(0.156 \mathrm{~g}, 1.39 \times 10^{-3} \mathrm{~mol}\right)$, 4-methoxybenzylamine $\left(0.18 \mathrm{~mL}, 1.39 \times 10^{-3} \mathrm{~mol}\right)$, acetic acid $\left(0.08 \mathrm{~mL}, 1.39 \times 10^{-3} \mathrm{~mol}\right)$ and cyclohexyl isocyanide $\left(0.17 \mathrm{~mL}, 1.39 \times 10^{-3} \mathrm{~mol}\right)$, compound 2a was obtained as an orange oil $\left(0.184 \mathrm{~g}, 4.6 \times 10^{-4} \mathrm{~mol}, 33 \%\right)$. ${ }^{1} \mathrm{H}$ NMR $(400 \mathrm{MHz}$, $\left.\mathrm{CDCl}_{3}\right): \delta=1.05-1.13$ (m, 3H, $3 \times H$-cHex), 1.24-1.33 (m, 2H, $2 \times H$-cHex), 1.50-1.62 (m, 3H, $3 \times$ $H$-cHex), 1.77-1.86 (m, 2H, $3 \times H$-cHex), 2.01 (s, 3H, $\left.\mathrm{CH}_{3} \mathrm{CO}\right), 3.70$ (s, 4H, $\mathrm{OCH}_{3}$ and $H 1$-cHex), $4.58\left(\mathrm{~s}, 2 \mathrm{H}, \mathrm{NCH}_{2}\right), 6.07(\mathrm{~s}, 1 \mathrm{H}, \alpha-\mathrm{H}), 6.23(\mathrm{~d}, J 8.0 \mathrm{~Hz}, 1 \mathrm{H}, \mathrm{NH}), 6.72$ (d, J 8.4 Hz, 2H, H3' and H5'), 6.87 (dd, J 3.4 and 5.0 Hz, 1H, H4), 6.95 (d, J 8.4 Hz, 2H, H2' and H6'), 7.05 (d, J 3.4 Hz, 1H, H3), $7.21(\mathrm{~d}, J 5.0 \mathrm{~Hz}, 1 \mathrm{H}, \mathrm{H} 5) .{ }^{13} \mathrm{C} \mathrm{NMR}\left(100.6 \mathrm{MHz}, \mathrm{CDCl}_{3}\right): \delta=22.15\left(\mathrm{CH}_{3} \mathrm{CO}\right), 24.43(C-$ cHex), 24.48 (C-cHex), 25.24 ( $C$-cHex), 32.38 (2 × C-cHex), 48.32 (C1-cHex), $50.07\left(\mathrm{NCH}_{2}\right), 54.96$ $\left(\mathrm{OCH}_{3}\right), 57.52(\alpha-\mathrm{CH}), 113.63\left(\mathrm{C}^{\prime}\right.$ ' and $\mathrm{C}^{\prime}$ '), $126.26(\mathrm{C} 4), 127.14(\mathrm{C} 5), 127.31$ (C2' and C6'), 129.02 (C3), 129.30 (C1'), 136.91 (C2), 158.42 (C4'), $167.62\left(\mathrm{C}^{\prime}=\mathrm{O}\right.$ amide), $171.95\left(\mathrm{CH}_{3} \mathrm{CO}\right)$; IR (liquid film, $\mathrm{cm}^{-1}$ ): $v=3306,3070,2933,2855,1633,1586,1542,1513,1464,1451,1409,1364$, 1350, 1289, 1247, 1207, 1176, 1111, 1093, 1036, 979, 912, 892, 840, 811, 735, 699, 665, 543. UV/Vis (ethanol, nm): $\lambda_{\max }(\log \varepsilon)=275$ (4.19). MS: $m / z$ (ESI, \%) $401\left(\mathrm{M}^{+}, 100\right) . \mathrm{HMRS}: \mathrm{m} / z$ (ESI) calc. for $\mathrm{C}_{22} \mathrm{H}_{29} \mathrm{~N}_{2} \mathrm{O}_{3} \mathrm{~S} 401.18934$, found 401.18900 .

\section{2-([2,2'-Bithiophen]-5-yl)- $N$-cyclohexyl-2-( $N$-(4'’-methoxybenzyl)acetamido)acetamide}

$2 h$.

Starting from 5-formyl-2,2'-bithiophene $1 \mathbf{h}\left(0.210 \mathrm{~g}, 1.08 \times 10^{-3} \mathrm{~mol}\right)$, 4-methoxybenzylamine $(0.14$ $\left.\mathrm{mL}, 1.08 \times 10^{-3} \mathrm{~mol}\right)$, acetic acid $\left(0.06 \mathrm{~mL}, 1.08 \times 10^{-3} \mathrm{~mol}\right)$ and cyclohexyl isocyanide $(0.13 \mathrm{~mL}$, $\left.1.08 \times 10^{-3} \mathrm{~mol}\right)$, compound $\mathbf{2 h}$ was obtained as an orange oil $\left(0.215 \mathrm{~g}, 4.45 \times 10^{-4} \mathrm{~mol}, 41 \%\right) .{ }^{1} \mathrm{H}$ NMR (400 MHz, $\mathrm{CDCl}_{3}$ ): $\delta=1.06-1.17$ (m, 3H, $3 \times H$-cHex), 1.27-1.36 (m, 2H, $2 \times H$-cHex), 1.54$1.66\left(\mathrm{~m}, 3 \mathrm{H}, 3 \times H\right.$-cHex), 1.80-1.92 (m, 2H, $2 \times H$-cHex), 2.08 (s, 3H, $\left.\mathrm{CH}_{3} \mathrm{CO}\right), 3.73\left(\mathrm{~s}, 4 \mathrm{H}, \mathrm{OCH}_{3}\right.$ and $H 1$-cHex $), 4.56-4.67\left(\mathrm{~m}, 2 \mathrm{H}, \mathrm{NCH}_{2}\right), 5.91(\mathrm{~s}, 1 \mathrm{H}, \alpha-\mathrm{H}), 6.23(\mathrm{~d}, J 7.2 \mathrm{~Hz}, 1 \mathrm{H}, \mathrm{NH}), 6.77(\mathrm{~d}, J$ $8.8 \mathrm{~Hz}, 2 \mathrm{H}, \mathrm{H} 3$ ', and H5' '), 6.92 (d, J 3.6 Hz, 1H, H3), 6.95 (d, J 3.6 Hz, 1H, H4), 6.96-6.98 (m, 1H, H4'), 7.06 (d, J 8.8 Hz, 2H, H2', and H6' ') 7.12 (d, J 2.8 Hz, 1H, H5'), 7.18 (d, J 5.2 Hz, 1H, H3'). ${ }^{13} \mathrm{C}$ NMR (100.6 MHz, $\left.\mathrm{CDCl}_{3}\right): \delta=22.21\left(\mathrm{CH}_{3} \mathrm{CO}\right), 24.53(C$-cHex $), 24.60(C$-cHex $), 25.32(C$ cHex), 32.48 ( $C$-cHex), 32.53 ( $C$-cHex $), 48.51$ ( $C 1$-cHex), $50.49\left(\mathrm{NCH}_{2}\right), 55.08\left(\mathrm{OCH}_{3}\right), 58.25(\alpha-$ $\mathrm{CH}), 113.81$ (C3', and C5'), 122.60 (C4), 123.75 (C5'), 124.50 (C3'), 127.59 (C2', and C6'), 127.69 (C4'), 128.83 (C1'’), 129.92 (C3), 135.73 (C2), 135.73 (C2'), 139.28 (C5), 158.65 (C4'”), $167.41\left(\mathrm{C}=\mathrm{O}\right.$ amide), $172.01\left(\mathrm{CH}_{3} \mathrm{CO}\right)$. IR (liquid film, $\left.\mathrm{cm}^{-1}\right): v=3297,3069,2932,2854,1654$, 1586, 1542, 1513, 1451, 1409, 1351, 1303, 1248, 1209, 1177, 1111, 1093, 1035, 979, 956, 918, 892, 
840, 811, 735, 699, 665, 543. UV/Vis (ethanol, nm): $\lambda_{\max }(\log \varepsilon)=310$ (4.23). MS: $m / z$ (ESI, \%) 483

$\left(\mathrm{M}^{+}, 100\right)$. HMRS: $m / z$ (ESI) calc. for $\mathrm{C}_{26} \mathrm{H}_{31} \mathrm{~N}_{2} \mathrm{O}_{3} \mathrm{~S}_{2} 483.17706$, found 483.17668.

\section{Spectrophotometric titrations and chemosensing studies for thienyl amino acids $\mathbf{2 a - j}$}

Solutions of compounds $2 \mathbf{a}-\mathbf{j}\left(1.0 \times 10^{-5}\right.$ to $\left.1.0 \times 10^{-6} \mathrm{M}\right)$ and of the ions under study $\left(1.0 \times 10^{-1}\right.$ to $1.0 \times 10^{-3} \mathrm{M}$ ) were prepared in UV-grade acetonitrile (in the form of hydrated tetrafluorborate salts for $\mathrm{Cu}^{+}, \mathrm{Ag}^{+}, \mathrm{Pd}^{2+}$ and $\mathrm{Co}^{2+}$, hydrated perchlorate salts for $\mathrm{K}^{+}, \mathrm{Cd}^{2+}, \mathrm{Ca}^{2+}, \mathrm{Fe}^{3+}, \mathrm{Fe}^{2+}, \mathrm{Cr}^{3+}, \mathrm{Cu}^{2+}$, $\mathrm{Ni}^{2+}, \mathrm{Cs}^{+}, \mathrm{Na}^{+}, \mathrm{Hg}^{2+}, \mathrm{Pb}^{2+}, \mathrm{Zn}^{2+}$ and hydrated tetrabutylammonium salts for $\mathrm{CH}_{3} \mathrm{COO}^{-}, \mathrm{F}^{-}, \mathrm{I}^{-}, \mathrm{ClO}_{4}^{-}$, $\mathrm{CN}^{-}, \mathrm{NO}_{3}^{-}, \mathrm{BzO}^{-}, \mathrm{Cl}^{-}, \mathrm{Br}^{-}$and $\left.\mathrm{OH}^{-}\right)$. Titration of the compounds with the several ions was performed by the sequential addition of ion to the compound solution, in a $10 \mathrm{~mm}$ path length quartz cuvette and emission spectra were measured by excitation at the wavelength of maximum absorption for each compound, indicated in Table 2, with a $2 \mathrm{~nm}$ slit. The linearity of the absorption versus concentration was checked within the used concentration. The binding stoichiometry of the thienyl amino acids with the ions was determined by Job's plots. The association constants were obtained with HypSpec program.

\section{Results and Discussion}

\section{Synthesis}

New non-canonical amino acids bearing thiophene and bithiopene units with substituents of different electronic character as side chains were obtained by an Ugi reaction. This reaction is an isocyanidebased four-component reaction proposed in 1959 by Ivar Ugi as an alternative to the classical methods for amino acid synthesis, by reacting an acid, an amine, an isocyanide and a carbonyl compound. Following the original application of the Ugi reaction, it can be used for the synthesis of $\alpha$-amino acids (if an aldehyde is used as the carbonyl component) and $\alpha, \alpha$-dialkylamino acids (if a ketone is used as the carbonyl component) (Dömling 2006; Costa et al. 2003). In this work, acetic acid, 4-methoxybenzylamine and cyclohexyl isocyanide were used, along with a series of thiophene and bithiophene aldehydes $\mathbf{1 a - j}$ bearing different substituents. The protected amino acids $\mathbf{2 a - \mathbf { j }}$ were prepared in fair to moderate yields (15-60\%) (Scheme 1, Table 1). These new compounds were fully characterised by the usual spectroscopic techniques. 


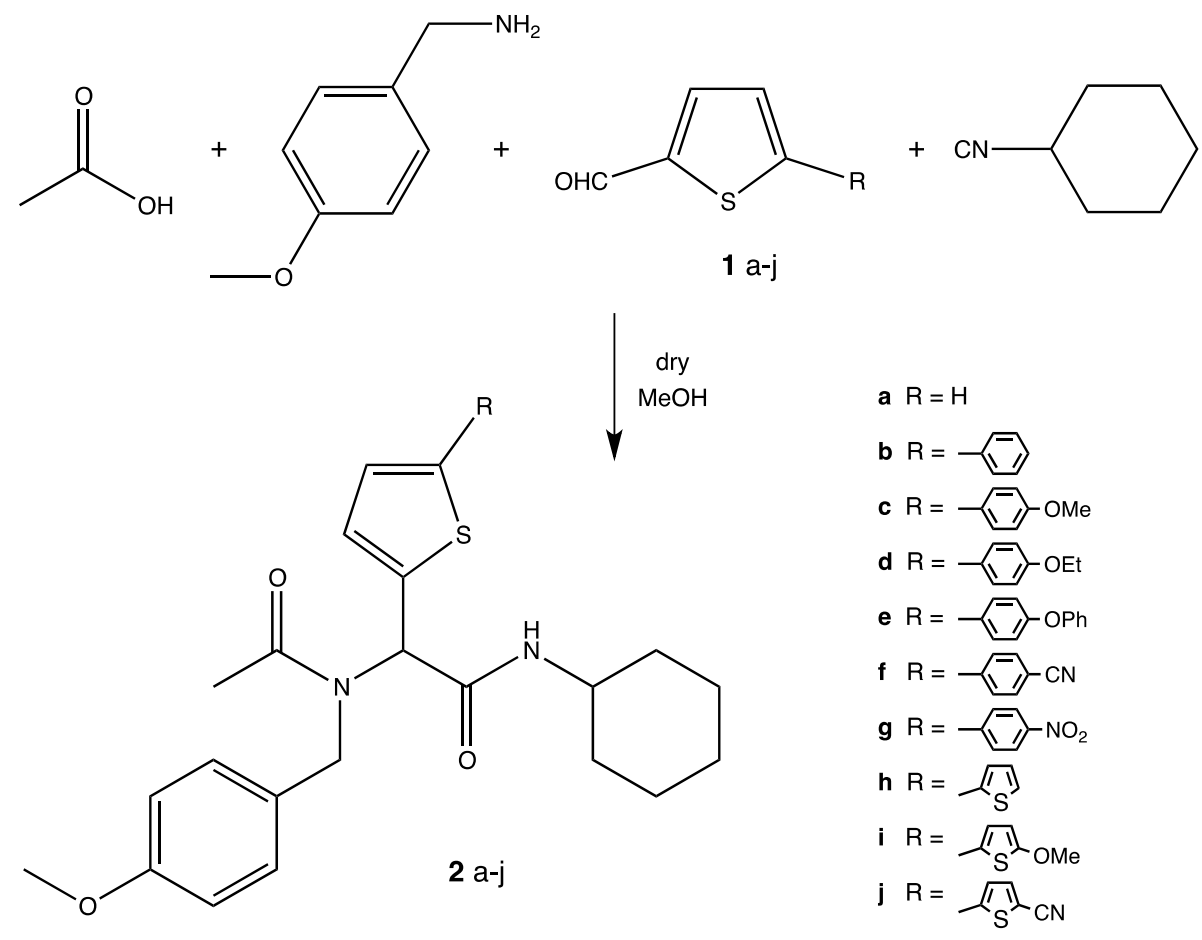

Scheme 1. Synthesis of (bi)thienyl amino acid derivatives $\mathbf{2 a - j}$.

Table 1. Yields, UV-visible absorption and fluorescence data for amino acids $\mathbf{2 a - j}$ in absolute ethanol.

\begin{tabular}{cccccccc}
\hline & & \multicolumn{3}{c}{ UV/Vis absorption } & \multicolumn{4}{c}{ Fluorescence } \\
\cline { 3 - 7 } Cpd. & Yield & log $\varepsilon$ & $\lambda_{\text {em }}$ & $\begin{array}{c}\text { Stokes' } \\
\text { shift }\left(\mathrm{cm}^{-1}\right)\end{array}$ & $\begin{array}{c}\text { Stokes' } \\
\text { shift }(\mathrm{nm})\end{array}$ & $\Phi_{\mathrm{F}}$ \\
\hline $\mathbf{2 a}$ & 33 & 276 & 3.60 & 303 & 3627 & 27 & 0.005 \\
$\mathbf{2 b}$ & 60 & 286 & 4.01 & 353 & 6636 & 67 & 0.089 \\
$\mathbf{2 c}$ & 25 & 298 & 3.55 & 362 & 5933 & 64 & 0.293 \\
$\mathbf{2 d}$ & 26 & 299 & 3.54 & 362 & 5821 & 63 & 0.284 \\
$\mathbf{2 e}$ & 21 & 299 & 4.25 & 358 & 5512 & 59 & 0.221 \\
$\mathbf{2 f}$ & 27 & 317 & 4.22 & 386 & 5639 & 69 & 0.039 \\
$\mathbf{2 g}$ & 34 & 349 & 4.21 & 511 & 9084 & 162 & 0.002 \\
$\mathbf{2 h}$ & 41 & 310 & 3.49 & 375 & 5591 & 65 & 0.420 \\
$\mathbf{2 i}$ & 41 & 327 & 4.31 & 402 & 5705 & 75 & 0.037 \\
$\mathbf{2 j}$ & 15 & 336 & 4.21 & 415 & 5666 & 79 & 0.124 \\
\hline
\end{tabular}


The acid, amine and isocyanide components were chosen considering previous work that ensures straightforward removal of the groups at the $N$ - and $C$-terminal by acidolysis to afford the free non canonical amino acids for subsequent use in peptide synthesis (Costa et al. 2003; Castro et al. 2016).

\section{Photophysical study of (bi)thienyl amino acid derivatives 2a-j}

The electron donor or acceptor character of the substituents envisaged the modulation of the photophysical and the recognition properties of the resulting compounds. Therefore, the absorption and emission spectra of (bi)thienyl amino acids derivatives $\mathbf{2 a - j}$ were measured in absolute ethanol $\left(10^{-6}-10^{-5} \mathrm{M}\right.$ solution) (Table 1). The nature of the substituent had a clear influence on the absorption and emission bands of compounds $\mathbf{2 a - j}$ (Figures 1 and 2).

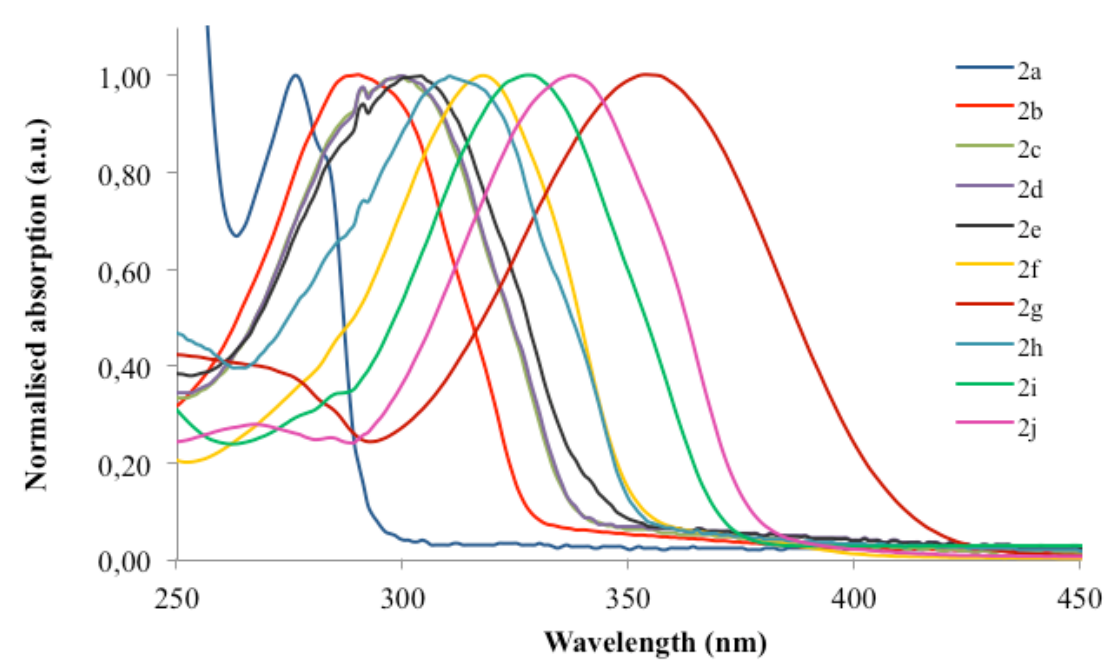

Figure 1. Normalised UV-visible absorption spectra of (bi)thienyl amino acids $\mathbf{2} \mathbf{a}-\mathbf{j}$ in $\mathrm{ACN}$ at $\mathrm{T}=$ 298 K.

By comparison to compound $\mathbf{2 a}$, as the parent compound, the presence of a phenyl ring bearing and electron donor group (as in 2c-e) lead to an expected bathochromic shift ( $c a .20 \mathrm{~nm}$ ) of the maximum wavelength of absorption ( $\left.\lambda_{\mathrm{abs}}\right)$. The bathochromic shift was more pronounced when electron acceptor groups were present: a $41 \mathrm{~nm}$ shift with the cyano group (for $\mathbf{2 f}$ ) and a $73 \mathrm{~nm}$ shift with the nitro group (for $\mathbf{2 g}$ ). The same trend was seen in the fluorescence spectra, with larger bathochromic shifts (especially for the nitro derivative with a $208 \mathrm{~nm}$ shift).

Comparison of the electronic absorption and emission spectra of compound $\mathbf{2 b}(\mathrm{R}=$ phenyl) with compound $2 \mathbf{h}(\mathrm{R}=$ thiophene), compound $\mathbf{2 c}(\mathrm{R}=$ methoxyphenyl), with $2 \mathbf{i}(\mathrm{R}=$ methoxythiophene), as well as comparison of derivative $\mathbf{2 f}(\mathrm{R}=$ cyanophenyl), with $\mathbf{2 j}$ ( $\mathrm{R}=$ cyanothiophene) revealed that the substitution of an aryl group by a thiophene caused a red shift of the maximum absorption 
(between 19-29 $\mathrm{nm}$ ) and emission (between 22-40 nm) wavelengths. This observation clearly indicates that the incorporation of thiophene units enhances the charge-transfer properties of the overall system and the optical data obtained can be largely explained by the bathochromic effect of sulphur and also the increase of the $\pi$-overlap between the thiophene units.

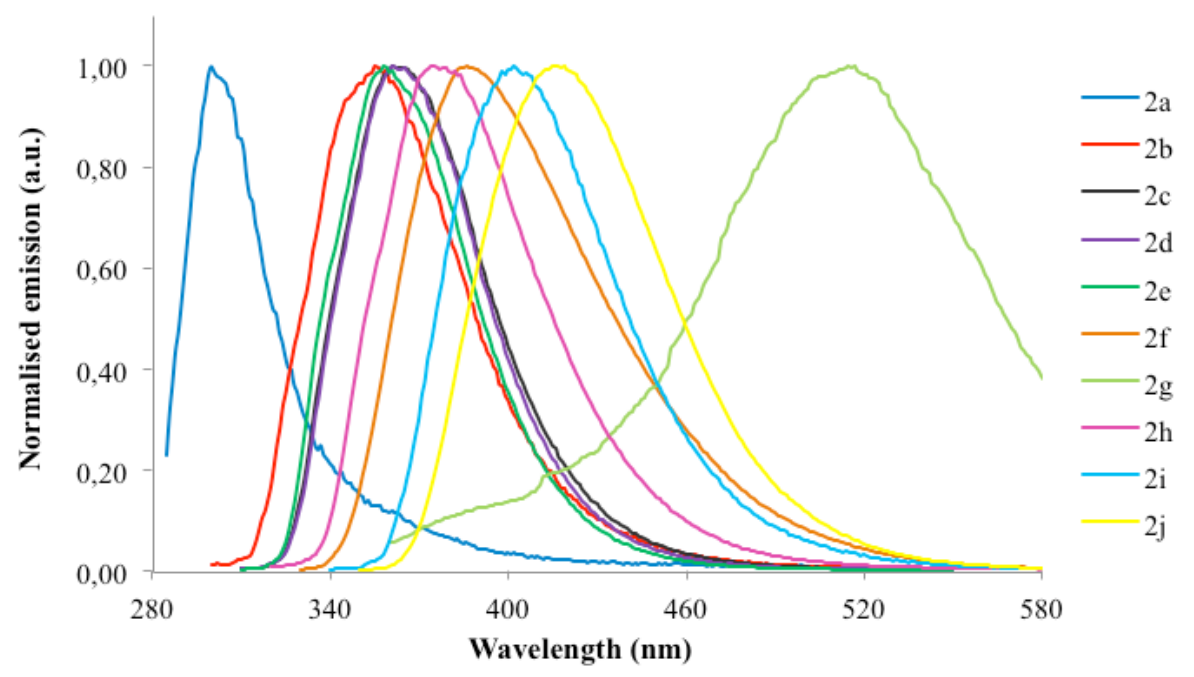

Figure 2. Normalised fluorescence spectra of (bi)thienyl amino acids $\mathbf{2 a - j}$ in $\mathrm{ACN}$ at $\mathrm{T}=298 \mathrm{~K}\left(\boldsymbol{\lambda}_{\mathrm{exc}}\right.$ $=\lambda_{\mathrm{abs}}$ for each compound).

The synthesized compounds showed moderate to large Stokes' shifts (the lowest being $3009 \mathrm{~cm}^{-1}$ for 2a and the highest $9084 \mathrm{~cm}^{-1}$ for $\mathbf{2 g}$ ). A large Stokes' shift is an interesting characteristic for a fluorescent probe, when using fluorescence based techniques, that allows an improved separation of the light inherent to the matrix and the light dispersed by the sample (Holler et al. 2002).

The relative fluorescence quantum yields of the ethanolic solutions of compounds $\mathbf{2 a - j}$ were determined using a $10^{-6} \mathrm{M}$ solution of 9,10-diphenylanthracene in ethanol as standard $\left(\Phi_{\mathrm{F}}=0.95\right)$ (Morris et al. 1976). It was found that the thienyl amino acids 2c-e (bearing donor groups) and bithienyl amino acids $2 \mathbf{h}, \mathbf{j}$ were the most emissive $\left(0.124 \leq \phi_{F} \leq 0.420\right)$. The most fluorescent derivative was compound $\mathbf{2 h}$ (bithiophene) and the presence of the nitro group resulted in an expected fluorescence quenching, with compound $\mathbf{2 g}$ being practically non-emissive in ethanol.

For the subsequent chemosensing study towards different ions, the absorption and emission spectra of (bi)thienyl amino acids $\mathbf{2 a - j}$ were also measured in acetonitrile $\left(10^{-6}-10^{-5} \mathrm{M}\right.$ solution) and its mixture with water (9:1) (Table 2). It was found that the presence of water did not influence the fluorescence quantum yields but the character of the solvent did, as the quantum yield was lower in ethanol (a protic solvent) when compared to acetonitrile (an aprotic solvent). 
Table 2. UV-visible absorption and fluorescence data for amino acids $\mathbf{2 a - j}$ in $\mathrm{ACN}, \mathrm{ACN} / \mathrm{H}_{2} \mathrm{O}(9: 1)$ and $\mathrm{EtOH} / / \mathrm{H}_{2} \mathrm{O}(9: 1)$.

\begin{tabular}{|c|c|c|c|c|c|c|c|}
\hline \multirow[b]{2}{*}{ Cpd. } & \multirow[b]{2}{*}{ Solvent } & \multicolumn{2}{|c|}{$\mathrm{UV} / \mathrm{Vis}$} & \multicolumn{4}{|c|}{ Fluorescence } \\
\hline & & $\lambda_{\max }$ & $\log \varepsilon$ & $\lambda_{\mathrm{em}}$ & $\begin{array}{c}\text { Stokes' } \\
\operatorname{shift}\left(\mathrm{cm}^{-1}\right)\end{array}$ & $\begin{array}{c}\text { Stokes' } \\
\text { shift ( nm) }\end{array}$ & $\Phi_{\mathrm{F}}$ \\
\hline \multirow{4}{*}{$2 \mathbf{a}$} & $\mathrm{ACN}$ & 276 & 3.48 & 301 & 3009 & 25 & 0.005 \\
\hline & $\mathrm{ACN} / \mathrm{H}_{2} \mathrm{O}(9: 1)$ & 276 & 3.61 & 301 & 3009 & 25 & 0.004 \\
\hline & $\mathrm{EtOH}$ & 276 & 3.60 & 303 & 3627 & 27 & 0.005 \\
\hline & $\mathrm{EtOH} / \mathrm{H}_{2} \mathrm{O}(9: 1)$ & 276 & 3.48 & 304 & 3337 & 28 & 0.005 \\
\hline \multirow{4}{*}{$2 b$} & $\mathrm{ACN}$ & 290 & 3.99 & 358 & 6550 & 68 & 0.099 \\
\hline & $\mathrm{ACN} / \mathrm{H}_{2} \mathrm{O}(9: 1)$ & 290 & 3.99 & 357 & 6472 & 67 & 0.094 \\
\hline & $\mathrm{EtOH}$ & 286 & 4.01 & 353 & 6636 & 67 & 0.089 \\
\hline & $\mathrm{EtOH} / \mathrm{H}_{2} \mathrm{O}(9: 1)$ & 286 & 3.97 & 354 & 6716 & 68 & 0.088 \\
\hline \multirow{4}{*}{$2 c$} & $\mathrm{ACN}$ & 298 & 3.53 & 362 & 5933 & 64 & 0.306 \\
\hline & $\mathrm{ACN} / \mathrm{H}_{2} \mathrm{O}(9: 1)$ & 299 & 3.56 & 363 & 5897 & 64 & 0.285 \\
\hline & $\mathrm{EtOH}$ & 299 & 3.55 & 362 & 5821 & 63 & 0.293 \\
\hline & $\mathrm{EtOH} / \mathrm{H}_{2} \mathrm{O}(9: 1)$ & 299 & 3.59 & 362 & 5821 & 63 & 0.273 \\
\hline \multirow{4}{*}{ 2d } & $\mathrm{ACN}$ & 299 & 3.48 & 362 & 5821 & 63 & 0.288 \\
\hline & $\mathrm{ACN} / \mathrm{H}_{2} \mathrm{O}(9: 1)$ & 299 & 3.49 & 363 & 5897 & 64 & 0.290 \\
\hline & $\mathrm{EtOH}$ & 300 & 3.54 & 362 & 5709 & 62 & 0.284 \\
\hline & $\mathrm{EtOH} / \mathrm{H}_{2} \mathrm{O}(9: 1)$ & 299 & 3.55 & 364 & 5972 & 65 & 0.294 \\
\hline \multirow{4}{*}{$2 e$} & $\mathrm{ACN}$ & 298 & 4.26 & 358 & 5624 & 60 & 0.250 \\
\hline & $\mathrm{ACN} / \mathrm{H}_{2} \mathrm{O}(9: 1)$ & 299 & 4.27 & 358 & 5512 & 59 & 0.221 \\
\hline & $\mathrm{EtOH}$ & 299 & 4.25 & 357 & 5434 & 58 & 0.221 \\
\hline & $\mathrm{EtOH} / \mathrm{H}_{2} \mathrm{O}(9: 1)$ & 299 & 4.24 & 358 & 5512 & 59 & 0.219 \\
\hline \multirow{3}{*}{$2 f$} & $\mathrm{ACN}$ & 318 & 4.22 & 386 & 5540 & 68 & 0.043 \\
\hline & $\mathrm{ACN} / \mathrm{H}_{2} \mathrm{O}(9: 1)$ & 318 & 4.21 & 389 & 5740 & 71 & 0.042 \\
\hline & $\mathrm{EtOH}$ & 317 & 4.22 & 386 & 5639 & 69 & 0.039 \\
\hline
\end{tabular}




\begin{tabular}{|c|c|c|c|c|c|c|c|}
\hline & $\mathrm{EtOH} / \mathrm{H}_{2} \mathrm{O}(9: 1)$ & 318 & 4.20 & 387 & 5607 & 69 & 0.038 \\
\hline \multirow{4}{*}{$2 \mathrm{~g}$} & $\mathrm{ACN}$ & 353 & 4.20 & 511 & 8759 & 158 & 0.006 \\
\hline & $\mathrm{ACN} / \mathrm{H}_{2} \mathrm{O}(9: 1)$ & 353 & 4.21 & 511 & 8759 & 158 & 0.004 \\
\hline & $\mathrm{EtOH}$ & 349 & 4.21 & 511 & 9084 & 162 & 0.002 \\
\hline & $\mathrm{EtOH} / \mathrm{H}_{2} \mathrm{O}(9: 1)$ & 352 & 4.18 & 511 & 8840 & 159 & 0.002 \\
\hline \multirow{4}{*}{$2 h$} & $\mathrm{ACN}$ & 310 & 3.51 & 375 & 5591 & 65 & 0.420 \\
\hline & $\mathrm{ACN} / \mathrm{H}_{2} \mathrm{O}(9: 1)$ & 309 & 3.47 & 375 & 5696 & 64 & 0.402 \\
\hline & $\mathrm{EtOH}$ & 310 & 3.49 & 375 & 5591 & 65 & 0.397 \\
\hline & $\mathrm{EtOH} / \mathrm{H}_{2} \mathrm{O}(9: 1)$ & 310 & 3.51 & 375 & 5591 & 65 & 0.374 \\
\hline \multirow{4}{*}{$2 \mathbf{i}$} & $\mathrm{ACN}$ & 327 & 4.31 & 403 & 5767 & 76 & 0.043 \\
\hline & $\mathrm{ACN} / \mathrm{H}_{2} \mathrm{O}(9: 1)$ & 328 & 4.31 & 405 & 5796 & 77 & 0.042 \\
\hline & $\mathrm{EtOH}$ & 327 & 4.31 & 402 & 5705 & 75 & 0.037 \\
\hline & $\mathrm{EtOH} / \mathrm{H}_{2} \mathrm{O}(9: 1)$ & 328 & 4.31 & 401 & 5550 & 73 & 0.039 \\
\hline \multirow{4}{*}{$2 \mathbf{j}$} & $\mathrm{ACN}$ & 337 & 4.20 & 417 & 5693 & 80 & 0.176 \\
\hline & $\mathrm{ACN} / \mathrm{H}_{2} \mathrm{O}(9: 1)$ & 337 & 4.21 & 419 & 5807 & 82 & 0.175 \\
\hline & $\mathrm{EtOH}$ & 336 & 4.21 & 415 & 5666 & 79 & 0.124 \\
\hline & $\mathrm{EtOH} / \mathrm{H}_{2} \mathrm{O}(9: 1)$ & 337 & 4.20 & 415 & 5577 & 78 & 0.143 \\
\hline
\end{tabular}

\section{Spectrophotometric and spectrofluorimetric titrations with ions}

The new (bi)thienyl amino acids $\mathbf{2} \mathbf{a}-\mathbf{j}$ were tested for their ability to act as fluorescent chemosensors in the recognition of biomedically relevant ions by performing spectrophotometric and spectrofluorimetric titrations in $\mathrm{ACN}$ and $\mathrm{ACN} / \mathrm{H}_{2} \mathrm{O}$ (9:1), in the presence of relevant organic and inorganic anions $\left(\mathrm{AcO}^{-}, \mathrm{F}^{-}, \mathrm{Cl}^{-}, \mathrm{Br}^{-}, \mathrm{I}^{-}, \mathrm{ClO}_{4}^{-}, \mathrm{CN}^{-}, \mathrm{NO}_{3}^{-}, \mathrm{BzO}^{-}, \mathrm{OH}^{-}, \mathrm{H}_{2} \mathrm{PO}_{4}^{-}\right.$and $\left.\mathrm{HSO}_{4}^{-}\right)$and of alkaline, alkaline-earth and transition metal cations $\left(\mathrm{Na}^{+}, \mathrm{K}^{+}, \mathrm{Cs}^{+}, \mathrm{Ag}^{+}, \mathrm{Cu}^{+}, \mathrm{Cu}^{2+}, \mathrm{Ca}^{2+}, \mathrm{Cd}^{2+}, \mathrm{Co}^{2+}\right.$, $\mathrm{Pb}^{2+}, \mathrm{Pd}^{2+}, \mathrm{Ni}^{2+}, \mathrm{Hg}^{2+}, \mathrm{Zn}^{2+}, \mathrm{Fe}^{2+}, \mathrm{Fe}^{3+}$ and $\left.\mathrm{Cr}^{3+}\right)$. As stated previously, the introduction of a UVactive and fluorescent heterocyclic unit at the side chain of the amino acid is expected to provide additional binding sites for a variety of ions. 
A preliminary evaluation of the chemosensing ability was performed by addition of 100 equiv of each cation/anion to solutions of amino acids $\mathbf{2 a - j}$ in acetonitrile and the changes in the intensity of the UV-vis absorption and fluorescence spectra were recorded.

In the UV-vis absorption spectra of the various amino acids in the presence of each tested ion, no changes were seen in the bands corresponding to the maximum wavelength of absorption, except for methoxybithienyl amino acid $\mathbf{2} \mathbf{i}$ in the presence of $\mathrm{Cu}^{2+}$. It was found that this amino acid is a very sensitive and selective colorimetric chemosensor for $\mathrm{Cu}^{2+}$ as it displayed a marked colour change from pale yellow to pink. Among all the other cations tested, only $\mathrm{Cu}^{+}$induced a minor pink coloration (Figure 3, top) that was negligible compared to that of $\mathrm{Cu}^{2+}$. The spectrophotometric titration with $\mathrm{Cu}^{2+}$ revealed that, upon addition of increasing amounts of the cation, the band at 327 $\mathrm{nm}$ decreased, accompanied by the appearance and increase of a new red-shifted band at $529 \mathrm{~nm}$ (Figure 3, bottom).

The same preliminary test was carried out in order to assess the changes (band shift and/or intensity) in the fluorescence spectra of the various amino acids in the presence of each tested ion. The nitro derivative $\mathbf{2 g}$ was not tested since it was practically non-fluorescent. This test revealed the ability of compounds $\mathbf{2 a - f}, \mathbf{h}-\mathbf{j}$ to interact especially with the more basic anions $\mathrm{F}^{-}$and $\mathrm{OH}^{-}$and with $\mathrm{Cu}^{2+}$ and $\mathrm{Fe}^{3+}$, with different sensitivity (the amount of ion necessary to induce changes in the fluorescence spectra depending on the compound). The sensing ability for anions was lower (requiring more equivalents for a significant fluorescence quenching, $c a$. 80-90\%) than for cations (which required less equivalents for a complete quenching). 

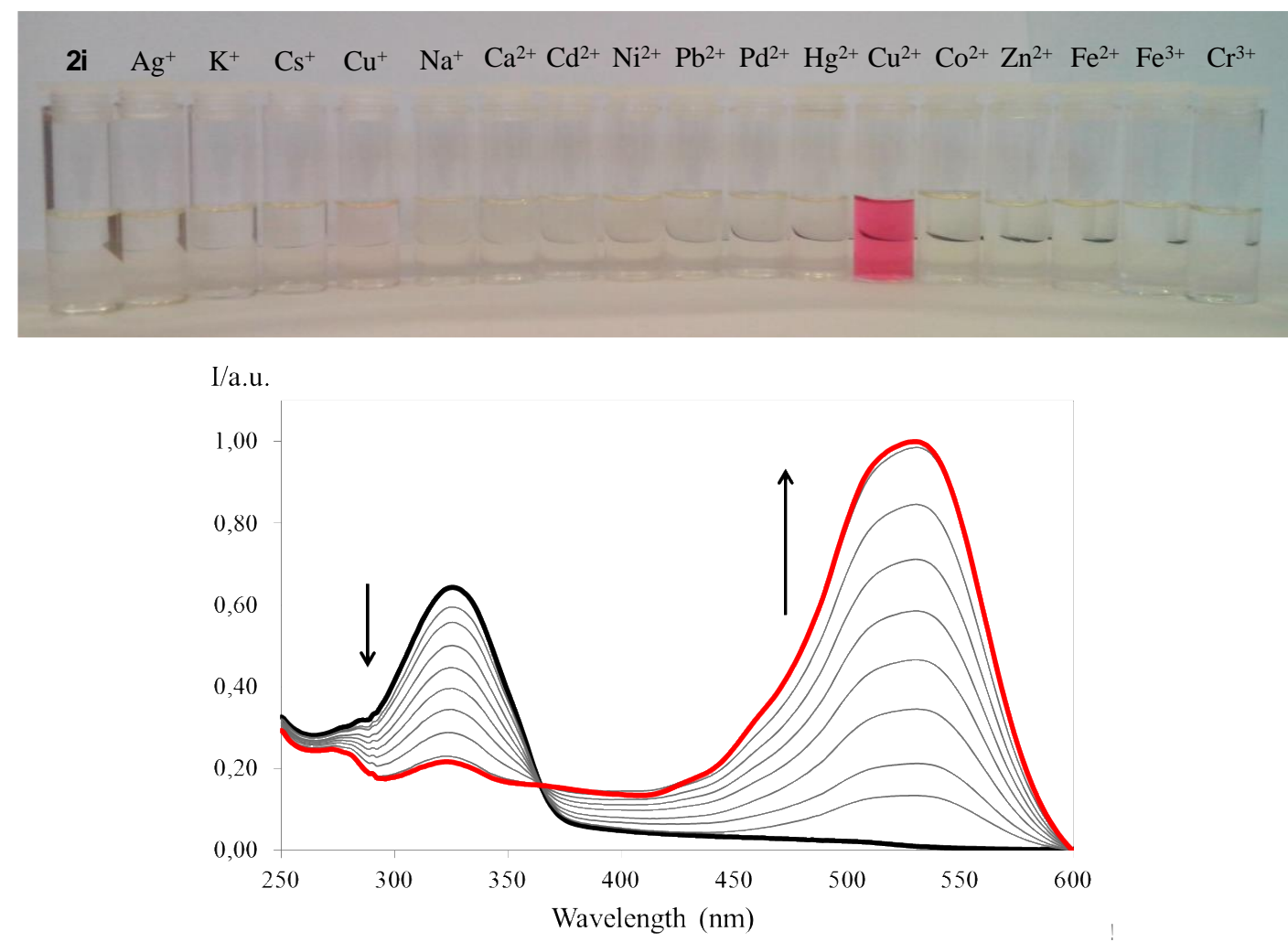

Figure 3. (top) Colour changes of bithienyl amino acid $2 \mathbf{i}$ in acetonitrile $\left(1.0 \times 10^{-4} \mathrm{~mol} \mathrm{dm}^{-3}\right)$ in the presence of 10 equiv of the various metal cations; (bottom) Spectrophotometric titration with $\mathrm{Cu}^{2+}$ (up to 5 equiv) in acetonitrile.

In the case of methoxybithienyl amino acid $\mathbf{2} \mathbf{i}$, chosen as representative example, in the spectrofluorimetric titrations with $\mathrm{F}^{-}$and $\mathrm{OH}^{-}$, upon addition of the anion it was visible the appearance and increase of a new band at $484 \mathrm{~nm}$ suggesting the formation of the deprotonated form of the amino acid due to the basicity of the anions. In the spectrofluorimetric titrations with $\mathrm{Cu}^{2+}$ and $\mathrm{Fe}^{3+}$, a considerable decrease of the fluorescence intensity was observed for (bi)thienyl amino acids 2a-f,h-j, with a small number of metal equivalents being necessary to completely quench fluorescence (Figure 4 for the titration of $\mathbf{2} \mathbf{i}$ with $\mathrm{F}^{-}, \mathrm{OH}^{-}, \mathrm{Cu}^{2+}$ and $\mathrm{Fe}^{3+}$ ). Also, for some amino acids the addition of much larger amounts (more than 100 equiv) of $\mathrm{Hg}^{2+}(\mathbf{2 h})$ and $\mathrm{Pd}^{2+}(\mathbf{2} \mathbf{b}-\mathbf{f}$ and $\mathbf{2 h})$ induced considerable but incomplete quenching. 

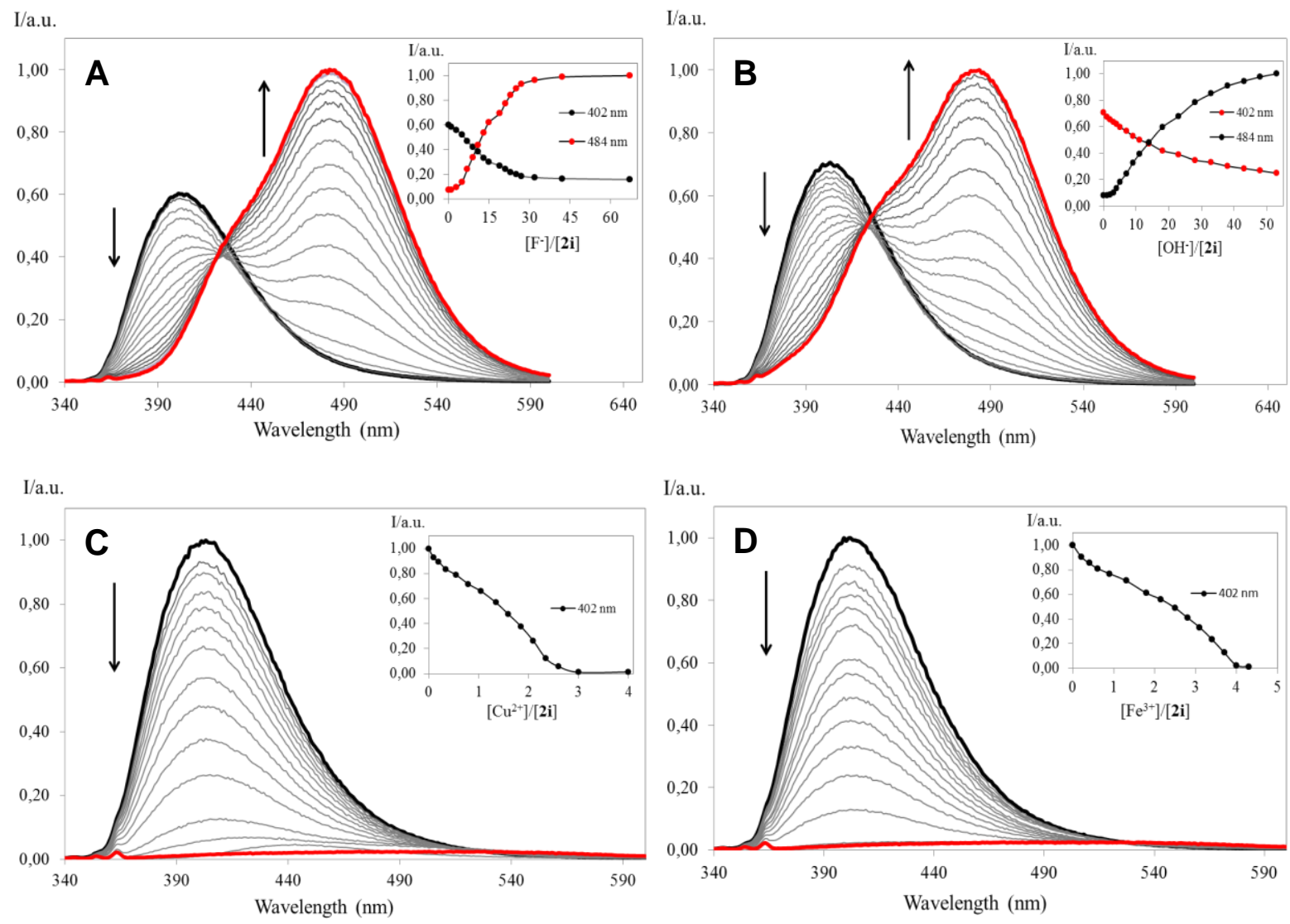

Figure 4. Fluorimetric titrations of bithienyl amino acid $2 \mathbf{i}$ with $\mathrm{F}^{-}(\mathrm{A}), \mathrm{OH}^{-}(\mathrm{B}), \mathrm{Cu}^{2+}(\mathrm{C})$ and $\mathrm{Fe}^{3+}$ (D), in acetonitrile $\left[\lambda_{\mathrm{exc}}=327 \mathrm{~nm}\right.$ ]. Inset: normalised emission at $402 \mathrm{~nm}$ and $484 \mathrm{~nm}$, as a function of added ion equivalents.

Association constants $\left(K_{\text {ass }}\right)$ between several amino acids and some selected ions were calculated from the spectrofluorimetric titration data with HypSpec program. The results suggested the formation of a ligand-metal(anion) complex with 2:1 stoichiometry (which was confirmed with Job's plots) and it was found that the new amino acids bind preferentially to $\mathrm{Fe}^{3+}$ and $\mathrm{Cu}^{2+}$ (Table 3 for anions and table 4 for cations). Although it cannot be stated that the new amino acids are selective for any cation, they display higher sensitivity for iron and copper as seen by the larger association constants. Moreover, the $K_{\text {ass }}$ obtained for the bithienyl amino acids $2 \mathbf{i}$ and $\mathbf{2} \mathbf{j}$ are higher than the corresponding thienyl amino acids $2 \mathbf{c}$ (bearing a methoxy group) and $\mathbf{2 f}$ (bearing a cyano group), showing the effect of the additional sulphur donor atom on the coordination ability. Previous studies on other heterocyclic amino acids have shown that free carboxylic and amino terminals did not influence significantly the coordination process, which should preferably occur through the heteroatoms at the side chain of the amino acids (Esteves et al. 2010). 
Table 3. Logarithm of association constants $\left(\log K_{\text {ass }}\right)$ for the interaction of (bi)thienyl amino acids $\mathbf{2 c - f , h - j}$ with several anions in acetonitrile (ligand:anion stoichiometry $2: 1$ ).

\begin{tabular}{rccc}
\hline Anion & $\mathbf{C N}^{-}$ & $\mathbf{F}^{-}$ & $\mathbf{O H}^{-}$ \\
\hline $\mathbf{2 c}$ & & & \\
\hline $\mathbf{2 d}$ & --- & $8.04 \pm 0.03$ & $10.39 \pm 0.05$ \\
$\mathbf{2 e}$ & --- & $8.55 \pm 0.04$ & --- \\
$\mathbf{2 f}$ & $11.47 \pm 0.07$ & $11.05 \pm 0.06$ & $11.09 \pm 0.06$ \\
$\mathbf{2 h}$ & $8.64 \pm 0.04$ & $8.48 \pm 0.02$ & $10.27 \pm 0.05$ \\
$\mathbf{2 i}$ & $8.61 \pm 0.03$ & $8.78 \pm 0.02$ & $7.1 \pm 0.2$ \\
$\mathbf{2 j}$ & $12.06 \pm 0.04$ & $12.44 \pm 0.05$ & $12.04 \pm 0.06$ \\
\hline
\end{tabular}

Table 4. Logarithm of association constants ( $\left.\log K_{\text {ass }}\right)$ for the interaction of (bi)thienyl amino acids $\mathbf{2 b - f , h - j}$ with several cations in acetonitrile (ligand:metal stoichiometry 2:1).

\begin{tabular}{rcccc}
\hline Cation & $\mathbf{C u}^{\mathbf{2 +}}$ & $\mathbf{F e}^{3+}$ & $\mathbf{H g}^{\mathbf{2 +}}$ & $\mathbf{P d}^{2+}$ \\
\hline $\mathbf{2 b}$ & $7.232 \pm 0.006$ & $7.233 \pm 0.007$ & -- & $7.247 \pm 0.005$ \\
$\mathbf{2 c}$ & $12.29 \pm 0.31$ & $11.33 \pm 0.29$ & --- & $11.09 \pm 0.07$ \\
$\mathbf{2 d}$ & $11.24 \pm 0.23$ & $11.35 \pm 0.24$ & -- & $11.07 \pm 0.08$ \\
$\mathbf{2 e}$ & $12.54 \pm 0.04$ & $13.38 \pm 0.05$ & --- & $12.15 \pm 0.06$ \\
$\mathbf{2 f}$ & $12.80 \pm 0.07$ & $12.00 \pm 0.06$ & -- & - \\
$\mathbf{2 h}$ & $11.42 \pm 0.20$ & $11.40 \pm 0.19$ & $11.07 \pm 0.08$ & $11.11 \pm 0.05$ \\
$\mathbf{2 i}$ & $13.33 \pm 0.10$ & $13.80 \pm 0.15$ & $11.97 \pm 0.07$ & $12.20 \pm 0.07$ \\
$\mathbf{2 j}$ & $13.21 \pm 0.05$ & $13.32 \pm 0.05$ & -- & $12.79 \pm 0.06$ \\
\hline
\end{tabular}




\section{Conclusions}

New heterocyclic amino acids 2 containing thiophene and bithiophene units as side chain were synthesised and evaluated as fluorescent chemosensors based on an amino acid core for a series of biomedically relevant ions. From the spectrofluorimetric titrations in acetonitrile, it was found that the (bi)thienyl amino acids were more sensitive towards $\mathrm{Fe}^{3+}$ and $\mathrm{Cu}^{2+}$, when compared to the other tested ions, as a very low number of metal equivalents was enough to obtain a complete fluorescence quenching. The results indicated that there is a strong interaction with $\mathrm{Fe}^{3+}$ and $\mathrm{Cu}^{2+}$ through the donor $\mathrm{N}, \mathrm{O}$ and $\mathrm{S}$ atoms at the side chain of the various amino acids and they can act as fluorimetric chemosensors. Interestingly, the methoxybithienyl amino acid $\mathbf{2} \mathbf{i}$ was found to be a very sensitive and selective colorimetric chemosensor for $\mathrm{Cu}^{2+}$ as it displayed a marked colour change from pale yellow to pink.

Due to their emissive properties and their recognition ability, these heterocyclic amino acids could find application as fluorescent building blocks for the preparation of peptides with chemosensory ability. Further studies will be undertaken in order to clarify aspects which are important for the pratical biomedical application of the synthesized compounds, such as the behaviour of these probes in the complex mixture of compounds in biological systems and their performance in the presence of ions and probes at physiological concentrations.

\section{Acknowledgments}

Thanks are due to Fundação para a Ciência e Tecnologia (FCT-Portugal) and FEDER-COMPETE for financial support through Centro de Química [PEst-C/QUI/UI0686/2013 (F-COMP-01-0124FEDER-037302)] and a PhD grant to C.I.C. Esteves (SFRH/BD/68360/2010). The NMR spectrometer Bruker Avance III 400 is part of the National NMR Network and was purchased with funds from FCT and FEDER.

\section{References}

Batista R M F, Ferreira R C M, Raposo M M M, Costa S P G (2012) Novel optical chemosensors for anions and cations based on an amino acid core functionalised with benzimidazoles. Tetrahedron 68:7322-7330.

Capobianco M L, Barbarella G, Manetto A (2012) Oligothiophenes as fluorescent markers for biological applications. Molecules 17:910-933. 
Castro V I B, Carvalho C M, Fernandes R D V, Pereira-Lima S M M A, Castanheira E M S, Costa S P G (2016) Peptaibolin analogues by incorporation of $\alpha, \alpha$-dialkylglycines: synthesis and study of their membrane permeating ability. Tetrahedron 72:1024-1030.

Cheruku P, Huang J-H, Yen H-J, Iyer R S, Rector K D, Martinez J S, Wang H-L (2015) Tyrosinederived stimuli responsive, fluorescent amino acids. Chem. Sci. 6:1150-1158.

Costa S P G, Maia H L S, Pereira-Lima S M M A (2003) An improved approach for the synthesis of $\alpha, \alpha$-dialkyl glycine derivatives by the Ugi-Passerini reaction. Org. Biomol. Chem. 1:1475-1479.

Costa SPG, Oliveira E, Lodeiro C, Raposo MMM (2007) Synthesis, characterization and metal ion detection of novel fluoroiono-phores based on heterocyclic substituted alanines. Sensors 7:2096-2114.

Costa SPG, Oliveira E, Lodeiro C, Raposo MMM (2008a) Heteroaromatic alanine derivatives bearing (oligo)thiophene units: synthe-sis and photophysical properties. Tetrahedron Lett 49:5258-5261.

Costa SPG, Batista RMF, Raposo MMM (2008b) Synthesis and photophysical characterization of new fluorescent bis-amino acids bearing a heterocyclic bridge containing benzoxazole and thiophene. Tetrahedron 64:9733-9737.

Dömling A (2006) Recent developments in isocyanide based multicomponent reactions in applied chemistry. Chem Rev 106:17-89.

Esteves C I C, Silva A M F, Raposo M M M, Costa S P G (2009) Unnatural benz-X-azolyl asparagine derivatives as novel fluorescent amino acids: synthesis and photophysical characterization. Tetrahedron 65:9373-9377.

Esteves C I C, Raposo M M M, Costa S P G (2010) Synthesis and evaluation of benzothiazolyl and benzimidazolyl asparagines as amino acid based selective fluorimetric chemosensors for $\mathrm{Cu}^{2+}$. Tetrahedron 66:7479-7486.

Esteves C I C, Raposo M M M, Costa S P G (2011) Novel highly emissive non-proteinogenic amino acids: synthesis of 1,3,4-thiadiazolyl asparagines and evaluation as fluorimetric chemosensors for biologically relevant transition metal cations. Amino Acids 40:1065-1075.

Esteves C I C, Batista R M F, Costa S P G, Raposo M M M (2016) Novel functionalised imidazobenzocrown ethers bearing a thiophene spacer as fluorimetric chemosensors for metal ion detection. Dyes Pigments, 135:134-142.

Hennig A, Florea M, Roth D, Enderle T, Nau W M (2007) Design of peptide substrates for nanosecond time-resolved fluorescence assays of proteases: 2,3-Diazabicyclo[2.2.2]oct-2-ene as a noninvasive fluorophore. Anal. Biochem. 360:255-265. 
Kajihara D, Abe R, Iijima I, Komiyama C, Sissido M, Hohsaka T (2006) FRET analysis of protein conformational change through position-specific incorporation of fluorescent amino acids. Nature Methods 3:923-929.

Katritzki A R, Narindoshvili T (2009) Fluorescent amino acids: advances in protein-extrinsic fluorophores. Org. Biomol. Chem. 7:627-624.

Lee S, Xie J, Chen X (2010) Peptide-based probes for targeted molecular imaging. Biochemistry 49:1364-1376.

Liu Q, Wang J, Boyd B J (2015) Peptide-based biosensors. Talanta 136:114-127.

Moragues M E, Martínez-Máñez R, Sancenón F (2011) Chromogenic and fluorogenic chemosensors and reagents for anions. A comprehensive review of the year 2009. Chem. Soc. Rev., 40:25932643.

Morris JV, Mahaney MA, Huber JR (1976) Fluorescence quantum yield determinations. 9,10Diphenylanthracene as a reference standard in different solvents. J Phys Chem 80:969-974.

Niu W, Guo J (2013) Expanding the chemistry of fluorescent protein biosensors through genetic incorporation of unnatural amino acids. Mol BioSyst 9:2961-2970.

Oliveira E, Genovese D, Juris R, Zaccheroni N, Capelo JL, Raposo MMM, Costa SPG, Prodi L, Lodeiro C (2011) Bioinspired systems for metal-ion sensing: new emissive peptide probes based on benzo[d]oxazole derivatives and their gold and silica nanoparticles. Inorg. Chem. 50:88348849.

Pina J J, de Melo S S, Batista R M F, Costa S P G, Raposo M M M (2010) Synthesis and Characterization of the Ground and Excited States of Tripodal-like Oligothienyl-imidazoles. J. Phys. Chem. B, 114:4964-4972.

Pless S A, Ahern C A (2013) Unnatural amino acids as probes of ligand-receptor interactions and their conformational consequences. Annu Rev Pharmacol Toxicol 53:211-29.

Santos-Figueroa L E, Moragues M E, Climent E, Agostini A, Martínez-Máñez R, Sancenón F (2013) Chromogenic and fluorogenic chemosensors and reagents for anions. A comprehensive review of the years 2010-2011. Chem. Soc. Rev. 42:3489-3613.

Shimazaki Y, Takani M, Yamauchi O (2009) Metal complexes of amino acids and amino acid side chain groups. Structure and properties. Dalton Trans 38:7854-7869.

Veale E B, Gunnlaugsson T (2010) Fluorescent sensors for ions based on organic structures. Annu. Rep. Prog. Chem. B Org. Chem. 106:376-406.

Wang A, Nairn N W, Marelli M, Grabstein K (2012) Protein engineering with non-natural amino acids. In: Kaumaya P. (ed) Protein Engineering, InTech, Rijeka, pp 253-290. 
Zheng Y, Cao X, Orbulescu J, Konka V, Andreopoulos F M, Pham S M, Leblanc R M (2003) Peptidyl Fluorescent Chemosensors for the Detection of Divalent Copper. Anal. Chem. 75:17061712.

Zhou L, Shao J, Li Q, van Heel A J, de Vries M P, Broos J, Kuipers O P (2016) Incorporation of tryptophan analogues into the lantibiotic nisin. Amino Acids 48:1309-1318. 


\section{Supplementary material}

1. Synthetic details and characterization for compounds $\mathbf{2} \mathbf{b}-\mathbf{g}, \mathbf{i}-\mathbf{j}$

$\mathrm{N}$-Cyclohexyl-2-(N-(4"'-methoxybenzyl)acetamido)-2-(5-phenylthiophen-2-yl)acetamide

$2 b$.

Starting from 2-(4'-formylphenyl)thiophene $\mathbf{1 b}\left(0.132 \mathrm{~g}, 7.03 \times 10^{-4} \mathrm{~mol}\right)$, 4-methoxybenzylamine $\left(0.09 \mathrm{~mL}, 7.03 \times 10^{-4} \mathrm{~mol}\right)$, acetic acid $\left(0.04 \mathrm{~mL}, 7.03 \times 10^{-4} \mathrm{~mol}\right)$ and cyclohexyl isocyanide $(0.09 \mathrm{~mL}$, $\left.7.03 \times 10^{-4} \mathrm{~mol}\right)$, compound $2 \mathrm{~b}$ was obtained as an orange oil $\left(0.201 \mathrm{~g}, 4.22 \times 10^{-4} \mathrm{~mol}, 60 \%\right) .{ }^{1} \mathrm{H}$ $\operatorname{NMR}\left(400 \mathrm{MHz}, \mathrm{CDCl}_{3}\right): \delta=1.10-1.19$ (m, 3H, $3 \times \mathrm{H}$-cHex), 1.28-1.38 (m, 2H, $2 \times \mathrm{H}$-cHex), 1.56-1.69 (m, 3H, $3 \times \mathrm{H}$-cHex), 1.83-1.92 (m, 2H, $2 \times \mathrm{H}$-cHex), $2.11\left(\mathrm{~s}, 3 \mathrm{H}, \mathrm{CH}_{3} \mathrm{CO}\right), 3.75\left(\mathrm{~s}, 4 \mathrm{H}, \mathrm{OCH}_{3}\right.$ and $\mathrm{H} 1$ cHex), 4.63 (d, J 8.0Hz, 2H, NCH $), 5.89(\mathrm{~s}, 1 \mathrm{H}, \alpha-\mathrm{H}), 6.01$ (d, J 7.6 Hz, 1H, NH), 6.79 (d, J $8.8 \mathrm{~Hz}, 2 \mathrm{H}$, H3" and H5"), 7.02 (d, J $3.6 \mathrm{~Hz}, 1 \mathrm{H}, \mathrm{H} 3$ ), 7.08 (d, J 8.6 Hz, 2H, H2" and H6"), 7.11 (d, J $3.6 \mathrm{~Hz}, 1 \mathrm{H}$, H4), 7.29 (d, J $7.2 \mathrm{~Hz}, 1 \mathrm{H}, \mathrm{H} 4^{\prime}$ ), 7.36 (t, J 7.2 Hz, 2H, H3' and H5'), 7.56 (d, J 7.2Hz, 2H, H2' and H6').

${ }^{13} \mathrm{C}$ NMR (100.6 MHz, CDCl 3$): \delta=22.37\left(\mathrm{CH}_{3} \mathrm{CO}\right), 24.68$ (C-cHex), 24.74 (C-cHex), 25.48 (C-cHex), 32.69 (C-cHex), 32.73 (C-cHex), 48.68 (C1-cHex), $50.78\left(\mathrm{NCH}_{2}\right), 55.26\left(\mathrm{OCH}_{3}\right), 58.73(\alpha-\mathrm{CH}), 113.97$ (C3" and C5'), 122.30 (C4), 125.79 (C2' and C6'), 127.70 (C2", C4' and C-6"), 128.90 (C3' and C5'), 129.25 (C1'), 130.42 (C3), 134.02 (C1'), 136.28 (C2), 146.36 (C5), 158.82 (C4'), 167.65 (C=O amide), $172.17\left(\mathrm{CH}_{3} \mathrm{CO}\right)$. IR (liquid film, $\left.\mathrm{cm}^{-1}\right): v=3301,3060,2931,2854,1649,1585,1544,1513,1462$, 1450, 1407, 1364, 1350, 1303, 1289, 1247, 1209, 1176, 1110, 1093, 1074, 1033, 978, 956, 917, 892, 813, 757, 701, 665, 543. UV/Vis (ethanol, nm): $\lambda_{\max }(\log \varepsilon)=286$ (4.01). MS: $m / z$ (ESI, \%) $477\left(\mathrm{M}^{+}\right.$, 100). HMRS: $m / z$ (ESI) calc. for $\mathrm{C}_{28} \mathrm{H}_{33} \mathrm{~N}_{2} \mathrm{O}_{3} \mathrm{~S} 477.22064$, found 477.22014 .

\section{N-Cyclohexyl-2-(N-(4"'-methoxybenzyl)acetamido)-2-(5-(4'-methoxyphenyl)thiophen-2-}

yl)acetamide 2c. Starting from 2-formyl-5-(4'-methoxyphenyl)thiophene 1c $\left(0.086 \mathrm{~g}, 3.95 \times 10^{-4}\right.$ mol), 4-methoxybenzylamine $\left(0.05 \mathrm{~mL}, 3.95 \times 10^{-4} \mathrm{~mol}\right)$, acetic acid $\left(0.02 \mathrm{~mL}, 3.95 \times 10^{-4} \mathrm{~mol}\right)$ and cyclohexyl isocyanide $\left(0.05 \mathrm{~mL}, 3.95 \times 10^{-4} \mathrm{~mol}\right)$, compound $2 \mathrm{c}$ was obtained as an orange oil $(0.050$ g, $\left.9.87 \times 10^{-5} \mathrm{~mol}, 25 \%\right) .{ }^{1} \mathrm{H}$ NMR $\left(400 \mathrm{MHz} \mathrm{CDCl}_{3}\right): \delta=1.07-1.18(\mathrm{~m}, 3 \mathrm{H}, 3 \times \mathrm{H}$-cHex), 1.26-1.38 (m, $2 \mathrm{H}, 2 \times \mathrm{H}$-cHex), 1.55-1.70 (m, 3H, $3 \times \mathrm{H}$-cHex), 1.82-1.94 (m, 2H, 2x $\times \mathrm{H}$-cHex), 2.10 (s, 3H, $\left.\mathrm{CH}_{3} \mathrm{CO}\right)$, $3.75\left(\mathrm{~s}, 4 \mathrm{H}, 4^{\prime \prime}-\mathrm{OCH}_{3}\right.$ and $\left.\mathrm{H} 1-\mathrm{cHex}\right), 3.83\left(\mathrm{~s}, 3 \mathrm{H}, 4^{\prime}-\mathrm{OCH}_{3}\right), 4.57-4.68\left(\mathrm{~m}, 2 \mathrm{H}, \mathrm{NCH}_{2}\right), 5.87(\mathrm{~s}, 1 \mathrm{H}, \alpha-\mathrm{H})$, $6.04(\mathrm{~d}, J 8.0 \mathrm{~Hz}, 1 \mathrm{H}, \mathrm{NH}), 6.78$ (d, J $8.4 \mathrm{~Hz}, 2 \mathrm{H}, \mathrm{H} 3^{\prime \prime}$ and H5'), 6.89 (d, J $8.8 \mathrm{~Hz}, 2 \mathrm{H}, \mathrm{H} 3^{\prime}$ and H5'), $6.99(\mathrm{~s}, 2 \mathrm{H}, \mathrm{H} 3$ and $\mathrm{H} 4), 7.08$ (d, J $8.4 \mathrm{~Hz}, 2 \mathrm{H}, \mathrm{H} 2^{\prime \prime}$ and $\mathrm{H}^{\prime \prime}$ ), 7.48 (d, J $8.8 \mathrm{~Hz}, 2 \mathrm{H}, \mathrm{H} 2^{\prime}$ and $\left.\mathrm{H}^{\prime}\right) .{ }^{13} \mathrm{C}$ 
$\operatorname{NMR}\left(100.6 \mathrm{MHz}, \mathrm{CDCl}_{3}\right): \delta=22.31\left(\mathrm{CH}_{3} \mathrm{CO}\right), 24.63$ (C-cHex), 24.69 (C-cHex), 25.42 (C-cHex), 32.62 (C-cHex), 32.66 (C-cHex), 48.59 (C1-cHex), $50.67\left(\mathrm{NCH}_{2}\right), 55.19\left(4^{\prime \prime}-\mathrm{OCH}_{3}\right), 55.29\left(4^{\prime}-\mathrm{OCH}_{3}\right), 58.69(\alpha-$ CH), 113.89 (C3' and C5'), 114.22 (C3' and C5'), 121.18 (C4), 126.81 (C1'), 127.00 (C2' and C6'), 127.70 (C2" and C6"), 129.01 (C1"), 130.32 (C3), 135.05 (C2), 146.24 (C5), 158.72 (C4"), 159.35 (C4'), 167.67 ( $\mathrm{C}=\mathrm{O}$ amide), $172.08\left(\mathrm{CH}_{3} \mathrm{CO}\right)$. IR (liquid film, $\left.\mathrm{cm}^{-1}\right): \mathrm{v}=3410,3297,3066,3001,2932$, 2854, 1650, 1632, 1612, 1586, 1544, 1513, 1463, 1409, 1364, 1351, 1287, 1249, 1177, 1111, 1090, 1033, 979, 957, 917, 892, 830, 805. UV/Vis (ethanol, nm): $\lambda_{\max }(\log \varepsilon)=299$ (4.21). MS: $m / z$ (ESI, \%) $507\left(\mathrm{M}^{+}, 100\right)$. HMRS: $\mathrm{m} / z$ (ESI) calc. for $\mathrm{C}_{29} \mathrm{H}_{35} \mathrm{~N}_{2} \mathrm{O}_{4} \mathrm{~S} 507.23120$, found 507.23085.

\section{N-Cyclohexyl-2-(N-(4"-methoxybenzyl)acetamido)-2-(5-(4'-ethoxyphenyl)thiophen-2-}

yl)acetamide $2 \mathrm{~d}$. Starting from 2-formyl-5-(4'-ethoxyphenyl)thiophene $1 \mathrm{~d}\left(0.187 \mathrm{~g}, 8.05 \times 10^{-4} \mathrm{~mol}\right)$, 4-methoxybenzylamine $\left(0.11 \mathrm{~mL}, 8.05 \times 10^{-4} \mathrm{~mol}\right)$, acetic acid $\left(0.05 \mathrm{~mL}, 8.05 \times 10^{-4} \mathrm{~mol}\right)$ and cyclohexyl isocyanide $\left(0.10 \mathrm{~mL}, 8.05 \times 10^{-4} \mathrm{~mol}\right)$, compound $\mathbf{2} \mathbf{d}$ was obtained as an orange oil $(0.109$ g, $\left.2.09 \times 10^{-4} \mathrm{~mol}, 26 \%\right) .{ }^{1} \mathrm{H}$ NMR $\left(400 \mathrm{MHz}, \mathrm{CDCl}_{3}\right): \delta=1.08-1.17(\mathrm{~m}, 3 \mathrm{H}, 3 \times \mathrm{H}$-cHex), 1.26-1.37 (m, $2 \mathrm{H}, 2 \times \mathrm{H}$-cHex), $1.40\left(\mathrm{t}, J 6.8 \mathrm{~Hz}, 3 \mathrm{H}, \mathrm{OCH}_{2} \mathrm{CH}_{3}\right), 1.54-1.67(\mathrm{~m}, 3 \mathrm{H}, 3 \times \mathrm{H}$-cHex), 1.81-1.93 (m, $2 \mathrm{H}, 2 \times$ $\mathrm{H}$-cHex), 2.07 (s, 3H, CH $\mathrm{CH}_{3} \mathrm{CO}$ ), $3.72\left(\mathrm{~s}, 4 \mathrm{H}, \mathrm{OCH}_{3}\right.$ and $\left.\mathrm{H} 1-\mathrm{cHex}\right), 4.02\left(\mathrm{q}, J 6.8 \mathrm{~Hz}, 2 \mathrm{H}, \mathrm{OCH}_{2} \mathrm{CH}_{3}\right), 4.56-$ $4.67\left(\mathrm{~m}, 2 \mathrm{H}, \mathrm{NCH}_{2}\right), 5.90(\mathrm{~s}, 1 \mathrm{H}, \alpha-\mathrm{H}), 6.18(\mathrm{~d}, J 2.4 \mathrm{~Hz}, 1 \mathrm{H}, \mathrm{NH}), 6.79$ (d, J $8.6 \mathrm{~Hz}, 2 \mathrm{H}, \mathrm{H}^{\prime \prime}$ ' and H5"), $6.86\left(\mathrm{~d}, J 8.8 \mathrm{~Hz}, 2 \mathrm{H}, \mathrm{H3}{ }^{\prime}\right.$ and $\left.\mathrm{H} 5^{\prime}\right), 6.97$ (s, 2H, H3 and H4), 7.06 (d, J 8.6 Hz, 2H, H2" and H6'), 7.44 (d, J 8.8Hz, 2H, H2' and $\left.\mathrm{H}^{\prime}\right) .{ }^{13} \mathrm{C} \mathrm{NMR}\left(100.6 \mathrm{MHz}, \mathrm{CDCl}_{3}\right): \delta=14.64\left(\mathrm{OCH}_{2} \mathrm{CH}_{3}\right), 22.23\left(\mathrm{CH}_{3} \mathrm{CO}\right)$, 24.55 (C-cHex), 24.61 (C-cHex), 25.50 (C-cHex), 32.50 (C-cHex), 32.53 (C-cHex), 48.50 (C1-cHex), $50.52\left(\mathrm{NCH}_{2}\right), 55.07\left(\mathrm{OCH}_{3}\right), 58.48(\alpha-\mathrm{CH}), 63.39\left(\mathrm{OCH}_{2} \mathrm{CH}_{3}\right), 113.78\left(\mathrm{C3}^{\prime \prime}\right.$ and $\left.\mathrm{C}^{\prime \prime}\right), 114.67\left(\mathrm{C}^{\prime}\right.$ and C5'), 121.03 (C4), 126.86 (C2' and C6'), 127.59 (C2' and C6"), 129.01 (C1"), 130.19 (C3), 131.86 (C1'), 135.05 (C2), 146.15 (C5), 158.60 (C4' and C4'), 167.62 (C=O amide), 172.02 ( $\mathrm{CH}_{3} \mathrm{CO}$ ). IR (liquid film, $\left.\mathrm{cm}^{-1}\right): v=3410,3297,3062,2979,2930,2855,1652,1611,1586,1572,1544,1513,1463$, $1408,1364,1351,1303,1287,1248,1177,1116,1090,1039,979,958,921,892,825,803$. UV/Vis (ethanol, $\mathrm{nm}): \lambda_{\max }(\log \varepsilon)=299$ (4.21). MS: $m / z(E S I, \%) 342\left(\mathrm{M}^{+}-178,100\right), 521\left(\mathrm{M}^{+}, 89\right)$. HMRS: $m / z$ (ESI) calc. for $\mathrm{C}_{30} \mathrm{H}_{37} \mathrm{~N}_{2} \mathrm{O}_{4} \mathrm{~S} 521.24685$, found 521.24652.

\section{N-Cyclohexyl-2-(N-(4"'-methoxybenzyl)acetamido)-2-(5-(4'-phenoxyphenyl)thiophen-2-}

yl)acetamide 2e. Starting from 2-formyl-5-(4'-phenoxyphenyl)thiophene 1 e $\left(0.188 \mathrm{~g}, 6.70 \times 10^{-4}\right.$ mol), 4-methoxybenzylamine $\left(0.09 \mathrm{~mL}, 6.70 \times 10^{-4} \mathrm{~mol}\right)$, acetic acid $\left(0.04 \mathrm{~mL}, 6.70 \times 10^{-4} \mathrm{~mol}\right)$ and 
cyclohexyl isocyanide $\left(0.08 \mathrm{~mL}, 6.70 \times 10^{-4} \mathrm{~mol}\right)$, compound $2 \mathrm{e}$ was obtained as an orange oil $(0.080$ g, $\left.1.41 \times 10^{-4} \mathrm{mmol}, 21 \%\right) .{ }^{1} \mathrm{H}$ NMR (300 MHz, $\left.\mathrm{CDCl}_{3}\right): \delta=1.10-1.19(\mathrm{~m}, 3 \mathrm{H}, 3 \times \mathrm{H}$-cHex), 1.26-1.40 $(\mathrm{m}, 2 \mathrm{H}, 2 \times \mathrm{H}$-cHex $), 1.55-1.70(\mathrm{~m}, 3 \mathrm{H}, 3 \times \mathrm{H}$-cHex $), 1.83-1.95(\mathrm{~m}, 2 \mathrm{H}, 2 \times \mathrm{H}$-cHex), $2.11(\mathrm{~s}, 3 \mathrm{H}$, $\mathrm{CH}_{3} \mathrm{CO}$ ), 3.75 (s, 4H, OCH and $\mathrm{H1}$-cHex), 4.63 (d, J 4.8Hz, 2H, $\mathrm{NCH}_{2}$ ), $5.89(\mathrm{br} \mathrm{s}, 1 \mathrm{H}, \alpha-\mathrm{H}), 6.04$ (d, J $7.8 \mathrm{~Hz}, 1 \mathrm{H}, \mathrm{NH}$ ), 6.79 (d, J 8.7 Hz, 2H, H3"' and H5"'”), 7.08 (d, J 8.7 Hz, 2H, H2"' and H6"'), 6.98-7.05 ( $\mathrm{m}, 6 \mathrm{H}, \mathrm{H} 3, \mathrm{H} 4, \mathrm{H2}{ }^{\prime \prime}, \mathrm{H}^{\prime}, \mathrm{H}^{\prime}$ and H6") 7.13 (dt, J 6.0 and $0.9 \mathrm{~Hz}, 1 \mathrm{H}, \mathrm{H} 4^{\prime \prime}$ ), 7.36 (dt, J 6.0 and 0.9 $\mathrm{Hz}, 2 \mathrm{H}, \mathrm{H}^{\prime \prime}$ and $\mathrm{H}^{\prime \prime}$ ), $7.51\left(\mathrm{~d}, J 8.7 \mathrm{~Hz}, 2 \mathrm{H}, \mathrm{H} 2^{\prime}\right.$ and $\left.\mathrm{H}^{\prime}\right) .{ }^{13} \mathrm{C} \mathrm{NMR}\left(75.4 \mathrm{MHz}, \mathrm{CDCl}_{3}\right): \delta=22.33$ ( $\mathrm{CH}_{3} \mathrm{CO}$ ), 24.63 (C-cHex), 24.69 (C-cHex), 25.42 (C-cHex), 32.63 (C-cHex), 32.68 (C-cHex), 48.61 (C1cHex), $50.68\left(\mathrm{NCH}_{2}\right), 55.20\left(\mathrm{OCH}_{3}\right), 58.63(\alpha-\mathrm{CH}), 113.90$ (C3"' and $\left.\mathrm{C}^{\prime \prime \prime}\right), 118.98$ (C2" and C6"), 119.02 (C3' and C5'), 121.80 (C4), 123.52 (C4'), 127.17 (C2' and C6'), 127.71 (C2'"' and C6'"'), 129.14 (C1"'), 129.78 (C3"' and C5"), 130.38 (C3), 135.79 (C2), 140.09 (C1'), 145.76 (C5), 156.79 (C1"), 157.08 (C4'), 158.75 (C4'”'), 167.61 (C=O amide), $172.11\left(\mathrm{CH}_{3} \mathrm{CO}\right)$. IR (liquid film, $\left.\mathrm{cm}^{-1}\right): v=3301$, 3060, 2931, 2854, 1649, 1585, 1544, 1513, 1462, 1450, 1407, 1364, 1350, 1303, 1289, 1247, 1209, 1176, 1110, 1093, 1074, 1033, 978, 956, 917, 892, 813, 757, 701, 665, 543. UV/Vis (ethanol, nm): $\lambda_{\max }(\log \varepsilon)=299$ (4.15). MS: $m / z$ (ESI, \%) $390\left(\mathrm{M}^{+}-178,100\right), 569\left(\mathrm{M}^{+}, 96\right)$. HMRS: $m / z$ (ESI) calc. for $\mathrm{C}_{34} \mathrm{H}_{37} \mathrm{~N}_{2} \mathrm{O}_{4} \mathrm{~S} 569.24685$, found 569.24654 .

\section{2-(5-(4'-Cyanophenyl)thiophen-2-yl)-N-cyclohexyl-2-(N-(4"-methoxybenzyl)acetamido)acetamide}

2f. Starting from 2-formyl-5-(4'-cyanophenyl)thiophene 1 f $\left(0.148 \mathrm{~g}, 6.97 \times 10^{-4} \mathrm{~mol}\right)$, 4methoxybenzylamine $\left(0.09 \mathrm{~mL}, 6.97 \times 10^{-4} \mathrm{~mol}\right)$, acetic acid $\left(0.04 \mathrm{~mL}, 6.97 \times 10^{-4} \mathrm{~mol}\right)$ and cyclohexyl isocyanide $\left(0.09 \mathrm{~mL}, 6.97 \times 10^{-4} \mathrm{~mol}\right)$, compound $2 \mathrm{f}$ was obtained as an orange oil (0.091 g, $\left.1.88 \times 10^{-4} \mathrm{~mol}, 27 \%\right) .{ }^{1} \mathrm{H}$ NMR $\left(300 \mathrm{MHz}, \mathrm{CDCl}_{3}\right): \delta=1.09-1.16(\mathrm{~m}, 3 \mathrm{H}, 3 \times \mathrm{H}$-cHex), 1.24-1.37 (m, $2 \mathrm{H}, 2 \times \mathrm{H}$-cHex), 1.54-1.67 (m, 3H, $3 \times \mathrm{H}$-cHex), 1.79-1.92 (m, 2H, $2 \times \mathrm{H}$-cHex), 2.11 (s, 3H, $\left.\mathrm{CH}_{3} \mathrm{CO}\right)$, $3.72\left(\mathrm{~s}, 4 \mathrm{H}, \mathrm{OCH}_{3}\right.$ and $\left.\mathrm{H} 1-\mathrm{cHex}\right), 4.61\left(\mathrm{~d}, J 3.0 \mathrm{~Hz}, 2 \mathrm{H}, \mathrm{NCH}_{2}\right), 5.97(\mathrm{~s}, 1 \mathrm{H}, \alpha-\mathrm{H}), 6.22(\mathrm{~d}, J 6.9 \mathrm{~Hz}, 1 \mathrm{H}$, $\mathrm{NH}), 6.76\left(\mathrm{~d}, J 7.2 \mathrm{~Hz}, 2 \mathrm{H}, \mathrm{H3} 3^{\prime \prime}\right.$ and H5"), 7.03 (d, J 7.2 Hz, 2H, H2" and H6"), 7.03 (d, J $3.9 \mathrm{~Hz}, 1 \mathrm{H}$, $\mathrm{H3}$ ), 7.19 (d, J $3.9 \mathrm{~Hz}, 1 \mathrm{H}, \mathrm{H} 4)$, 7.58-7.63 (m, 4H, H2', H3', H5' and $\left.\mathrm{H6}^{\prime}\right) .{ }^{13} \mathrm{C} \mathrm{NMR}\left(75.4 \mathrm{MHz}, \mathrm{CDCl}_{3}\right)$ : $\delta=22.25\left(\mathrm{CH}_{3} \mathrm{CO}\right), 24.54$ (C-cHex), 24.59 (C-cHex), 25.30 (C-cHex), 32.49 (C-cHex), 32.54 (C-cHex), 48.61 (C1-cHex), $50.49\left(\mathrm{NCH}_{2}\right), 55.13\left(\mathrm{OCH}_{3}\right), 58.06(\alpha-\mathrm{CH}), 110.59\left(\mathrm{C}^{\prime}\right), 113.85$ (C3" and C5"), 118.63 (CN), 124.13 (C4), 125.81 (C2' and C6'), 127.60 (C2"' and C6"'), 128.63 (C1'), 130.51 (C3), 132.58 (C3' and C5'), 138.19 (C1'), 138.68 (C2), 143.62 (C5), 158.73 (C4'), 167.23 (C=O amide), $172.15\left(\mathrm{CH}_{3} \mathrm{CO}\right)$. IR (liquid film, $\left.\mathrm{cm}^{-1}\right): v=3301,3061,2999,2933,2855,2226,1657,1604$ 1586, 
$1538,1513,1463,1451,1409,1364,1350,1303,1289,1248,1208,1177,1111,1092,1034,979$, 958, 941, 918, 892, 838, 814, 736, 701, 665, 543, 514. UV/Vis (ethanol, nm): $\lambda_{\max }(\log \varepsilon)=317$ (4.22). MS: $m / z$ (ESI, \%) $502\left(\mathrm{M}^{+}, 100\right)$. HMRS: $m / z$ (ESI) calc. for $\mathrm{C}_{29} \mathrm{H}_{32} \mathrm{~N}_{3} \mathrm{O}_{3} \mathrm{~S} 502.21589$, found 502.21535 .

\section{N-Cyclohexyl-2-(N-(4"-methoxybenzyl)acetamido)-2-(5-(4'-nitrophenyl)thiophen-2-yl)acetamide}

2g. Starting from 2-formyl-5-(4'-nitrophenyl)thiophene $\mathbf{1 g}\left(0.186 \mathrm{~g}, 8.00 \times 10^{-4} \mathrm{~mol}\right)$, 4methoxybenzylamine $\left(0.10 \mathrm{~mL}, 8.00 \times 10^{-4} \mathrm{~mol}\right)$, acetic acid $\left(0.05 \mathrm{~mL}, 8.00 \times 10^{-4} \mathrm{~mol}\right)$ and cyclohexyl isocyanide $\left(0.10 \mathrm{~mL}, 8.00 \times 10^{-4} \mathrm{~mol}\right)$, compound $\mathbf{2 g}$ was obtained as a yellow oil $(0.137$ g, $\left.2.72 \times 10^{-4} \mathrm{~mol}, 34 \%\right) .{ }^{1} \mathrm{H}$ NMR $\left(400 \mathrm{MHz}, \mathrm{CDCl}_{3}\right): \delta=1.09-1.16(\mathrm{~m}, 3 \mathrm{H}, 3 \times \mathrm{H}$-cHex), 1.27-1.32 (m, $2 \mathrm{H}, 2 \times \mathrm{H}$-cHex), 1.61-1.66 (m, 3H, $3 \times \mathrm{H}$-cHex), 1.82-1.93 (m, 2H, $2 \times \mathrm{H}$-cHex), $2.10\left(\mathrm{~s}, 3 \mathrm{H}, \mathrm{CH}_{3} \mathrm{CO}\right)$, $3.71\left(\mathrm{~s}, 4 \mathrm{H}, \mathrm{OCH}_{3}\right.$ and $\left.\mathrm{H} 1-\mathrm{cHex}\right), 4.62\left(\mathrm{~d}, J 8.0 \mathrm{~Hz}, 2 \mathrm{H}, \mathrm{NCH}_{2}\right), 6.03(\mathrm{~s}, 1 \mathrm{H}, \alpha-\mathrm{H}), 6.33(\mathrm{~d}, J 7.6 \mathrm{~Hz}, 1 \mathrm{H}$, $\mathrm{NH}), 6.75$ (d, J $8.8 \mathrm{~Hz}, 2 \mathrm{H}, \mathrm{H3}$ " and H5"), 7.03 (d, J $3.6 \mathrm{~Hz}, 1 \mathrm{H}, \mathrm{H3}$ ), 7.06 (d, J $8.6 \mathrm{~Hz}, 2 \mathrm{H}, \mathrm{H} 2^{\prime \prime}$ and H6”'), 7.23 (d, J $3.6 \mathrm{~Hz}, 1 \mathrm{H}, \mathrm{H} 4), 7.63\left(\mathrm{t}, J 7.2 \mathrm{~Hz}, 2 \mathrm{H}, \mathrm{H} 2^{\prime}\right.$ and H6'), 8.14 (d, J 7.2Hz, 2H, H3' and H5'). ${ }^{13} \mathrm{C}$ NMR (100.6 MHz, $\mathrm{CDCl}_{3}$ ): $\delta=22.22\left(\mathrm{CH}_{3} \mathrm{CO}\right), 24.52$ (C-cHex), 24.57 (C-cHex), 25.29 (C-cHex), 32.45 (C-cHex), 32.52 (C-cHex), 48.59 (C1-cHex), $50.39\left(\mathrm{NCH}_{2}\right), 55.09\left(\mathrm{OCH}_{3}\right), 57.89(\alpha-\mathrm{CH}), 113.82$ (C3' and C5'), 124.18 (C3' and C5'), 124.68 (C4), 125.70 (C2' and C6'), 127.57 (C2' and C6'), 128.64 (C1"), 130.52 (C3), 139.43 (C2), 140.09 (C1'), 143.00 (C5), 146.51 (C4'), 158.71 (C4'), 167.14 (C=O amide), $172.11\left(\mathrm{CH}_{3} \mathrm{CO}\right)$. IR (liquid film, $\left.\mathrm{cm}^{-1}\right): v=3301,3066,2931,2854,1737,1648,1630,1588$, $1543,1512,1489,1463,1408,1364,1350,1303,1288,1243,1202,1171,1108,1071,1035,978$, $958,916,891,869,836,803,751,736,660,512,503$. UV/Vis (ethanol, nm): $\lambda_{\max }(\log \varepsilon)=349$ (4.21). MS: $m / z$ (ESI, \%) $522\left(\mathrm{M}^{+}, 100\right)$. HMRS: $m / z$ (ESI) calc. for $\mathrm{C}_{28} \mathrm{H}_{32} \mathrm{~N}_{3} \mathrm{O}_{5} \mathrm{~S} 522.20572$, found 522.20509 .

\section{N-Cyclohexyl-2-(5'-methoxy-[2,2'-bithiophen]-5-yl)-2-(N-(4"'-}

methoxybenzyl)acetamido)acetamide $2 \mathbf{i}$. Starting from 5-formyl-5'-methoxy-2,2'-bithiophene $\mathbf{1} \mathbf{i}$ $\left(0.142 \mathrm{~g}, 6.34 \times 10^{-4} \mathrm{~mol}\right)$, 4-methoxybenzylamine $\left(0.08 \mathrm{~mL}, 6.34 \times 10^{-4} \mathrm{~mol}\right)$, acetic acid $(0.04 \mathrm{~mL}$, $\left.6.34 \times 10^{-4} \mathrm{~mol}\right)$ and cyclohexyl isocyanide $\left(0.08 \mathrm{~mL}, 6.34 \times 10^{-4} \mathrm{~mol}\right)$, compound $2 \mathbf{i}$ was obtained as an orange oil $\left(0.131 \mathrm{~g}, 2.60 \times 10^{-4} \mathrm{~mol}, 41 \%\right) .{ }^{1} \mathrm{H} \mathrm{NMR}\left(400 \mathrm{MHz}, \mathrm{CDCl}_{3}\right): \delta=1.08-1.16(\mathrm{~m}, 3 \mathrm{H}, 3 \times H-$ cHex), 1.26-1.32 (m, 2H, $2 \times H$-cHex), 1.53-1.66 (m, 3H, $3 \times H$-cHex), 1.79-1.90 (m, 2H, $2 \times H$-cHex), $2.06\left(\mathrm{~s}, 3 \mathrm{H}, \mathrm{CH}_{3} \mathrm{CO}\right), 3.73\left(\mathrm{~s}, 4 \mathrm{H}, 4^{\prime \prime}-\mathrm{OCH}_{3}\right.$ and $\left.\mathrm{H} 1-\mathrm{cHex}\right), 3.86\left(\mathrm{~s}, 3 \mathrm{H}, 4^{\prime}-\mathrm{OCH}_{3}\right), 4.54-4.65(\mathrm{~m}, 2 \mathrm{H}$, 
$\left.\mathrm{NCH}_{2}\right), 5.86(\mathrm{~s}, 1 \mathrm{H}, \alpha-\mathrm{H}), 6.08\left(\mathrm{~d}, J 3.8 \mathrm{~Hz}, 1 \mathrm{H}, \mathrm{H} 4^{\prime}\right), 6.21(\mathrm{br} \mathrm{s}, 1 \mathrm{H}, \mathrm{NH}), 6.74(\mathrm{~d}, J 4.0 \mathrm{~Hz}, 2 \mathrm{H}, \mathrm{H} 3$ and H4), 6.77 (d, J $8.4 \mathrm{~Hz}, 2 \mathrm{H}, \mathrm{H3} 3^{\prime \prime}$ and H5"), 6.87 (d, J $\left.3.8 \mathrm{~Hz}, 1 \mathrm{H}, \mathrm{H} 3^{\prime}\right), 7.05$ (d, J $8.4 \mathrm{~Hz}, 2 \mathrm{H}, \mathrm{H} 2^{\prime \prime}$ and H6"). ${ }^{13} \mathrm{C}$ NMR (100.6 MHz, $\left.\mathrm{CDCl}_{3}\right): \delta=22.22$ ( $\left.\mathrm{CH}_{3} \mathrm{CO}\right), 24.57$ (C-cHex), 24.64 (C-cHex), 25.36 (CcHex), 32.53 (C-cHex), 32.57 (C-cHex), 48.53 (C1-cHex), $50.58\left(\mathrm{NCH}_{2}\right), 55.12\left(4^{\prime \prime}-\mathrm{OCH}_{3}\right), 58.48(\alpha-$ $\mathrm{CH}), 60.14\left(4^{\prime}-\mathrm{OCH}_{3}\right), 104.32$ (C4'), 113.84 (C3"' and C5'), 121.07 (C4), 121.52 (C3), 123.23 (C5'), 127.65 (C2" and C6"), 128.88 (C1"), 129.88 (C3'), 134.47 (C2), 140.04 (C5), 158.68 (C4"), 165.66 (C2'), 167.49 (C=O amide), $172.00\left(\mathrm{CH}_{3} \mathrm{CO}\right)$. IR (liquid film, $\left.\mathrm{cm}^{-1}\right): v=3411,3302,3068,3007,2933$, $2854,1650,1632,1586,1532,1513,1498,1462,1451,1408,1350,1303,1289,1249,1202,1176$, $1111,1092,1052,1036,993,911,892,873,803,770,732,646,510$. UV/Vis (ethanol, nm): $\lambda_{\max }(\log$ $\varepsilon)=329$ (4.20). MS: $m / z$ (ESI, \%) $334\left(\mathrm{M}^{+}-178,100\right), 513\left(\mathrm{M}^{+}, 49\right)$. HMRS: $m / z$ (ESI) calc. for $\mathrm{C}_{27} \mathrm{H}_{33} \mathrm{~N}_{2} \mathrm{O}_{4} \mathrm{~S}_{2}$ 513.18763, found 513.18750.

\section{2-(5'-Cyano-[2,2'-bithiophen]-5-yl)-N-cyclohexyl-2-(N-(4"'-methoxybenzyl)acetamido)acetamide}

2j. Starting from 5'-cyano-5-formyl-2,2'-bithiophene $\mathbf{1 j}\left(0.175 \mathrm{~g}, 8.00 \times 10^{-4} \mathrm{~mol}\right)$, 4methoxybenzylamine $\left(0.10 \mathrm{~mL}, 8.00 \times 10^{-4} \mathrm{~mol}\right)$, acetic acid $\left(0.05 \mathrm{~mL}, 8.00 \times 10^{-4} \mathrm{~mol}\right)$ and cyclohexyl isocyanide $\left(0.10 \mathrm{~mL}, 8.00 \times 10^{-4} \mathrm{~mol}\right)$, compound $2 \mathbf{j}$ was obtained as an orange oil $(0.052$ g, $\left.1.20 \times 10^{-4} \mathrm{~mol}, 15 \%\right) .{ }^{1} \mathrm{H}$ NMR (400 MHz, $\left.\mathrm{CDCl}_{3}\right): \delta=1.10-1.19(\mathrm{~m}, 3 \mathrm{H}, 3 \times \mathrm{H}$-cHex), 1.26-1.35 (m, $2 \mathrm{H}, 2 \times \mathrm{H}$-cHex), 1.57-1.70 (m, 3H, $3 \times \mathrm{H}$-cHex), 1.83-1.93 (m, 2H, $2 \times \mathrm{H}$-cHex), $2.14\left(\mathrm{~s}, 3 \mathrm{H}, \mathrm{CH}_{3} \mathrm{CO}\right)$, $3.76\left(\mathrm{~s}, 4 \mathrm{H}, \mathrm{OCH}_{3}\right.$ and $\left.\mathrm{H} 1-\mathrm{cHex}\right), 4.60\left(\mathrm{~s}, 2 \mathrm{H}, \mathrm{NCH}_{2}\right), 5.93(\mathrm{~s}, 1 \mathrm{H}, \alpha-\mathrm{H}), 6.11(\mathrm{~d}, J 8.0 \mathrm{~Hz}, 1 \mathrm{H}, \mathrm{NH}), 6.79$ (d, J $8.4 \mathrm{~Hz}, 2 \mathrm{H}, \mathrm{H} 3^{\prime \prime}$ and H5"), 6.95 (d, J $3.8 \mathrm{~Hz}, 1 \mathrm{H}, \mathrm{H} 3$ ), 7.04 (d, J $8.4 \mathrm{~Hz}, 2 \mathrm{H}, \mathrm{H2}$ "' and H6"), 7.06 (d, J $3.8 \mathrm{~Hz}, 1 \mathrm{H}, \mathrm{H} 4), 7.09$ (d, J $\left.3.8 \mathrm{~Hz}, 1 \mathrm{H}, \mathrm{H3}{ }^{\prime}\right), 7.51$ (d, J $\left.3.8 \mathrm{~Hz}, 1 \mathrm{H}, \mathrm{H} 4^{\prime}\right) .{ }^{13} \mathrm{C} \mathrm{NMR}\left(100.6 \mathrm{MHz}, \mathrm{CDCl}_{3}\right)$ : $\delta=22.28\left(\mathrm{CH}_{3} \mathrm{CO}\right), 24.60$ (C-cHex), 24.65 (C-cHex), 25.39 (C-cHex), 32.58 (C-cHex), 32.65 (C-cHex), 48.72 (C1-cHex), $50.62\left(\mathrm{NCH}_{2}\right), 55.25\left(\mathrm{OCH}_{3}\right), 58.10(\alpha-\mathrm{CH}), 107.61\left(\mathrm{C5}^{\prime}\right), 113.98$ (C3" and C5"), 114.12 (CN), 123.50 (C3'), 124.85 (C4), 127.74 (C2" and C6"), 128.47 (C1"), 130.33 (C5'), 136.84 (C2'), 138.23 (C4'), 138.48 (C2), 144.29 (C5), 158.92 (C4'), 167.17 (C=O amide), 172.25 ( $\mathrm{CH}_{3} \mathrm{CO}$ ). IR (liquid film, cm $\mathrm{cm}^{-1}$ ): $v=3302,3070,2998,2932,2854,2217,1652,1586,1532,1513,1464,1451$, $1436,1407,1363,1351,1303,1292,1248,1207,1177,1112,1093,1035,979,963,918,805,736$, 709, 512. UV/Vis (ethanol, $\mathrm{nm}): \lambda_{\max }(\log \varepsilon)=337$ (4.21). MS: $m / z$ (ESI, \%) $508\left(\mathrm{M}^{+}, 100\right)$. HMRS: $m / z$ (ESI) calc. for $\mathrm{C}_{27} \mathrm{H}_{30} \mathrm{~N}_{3} \mathrm{O}_{3} \mathrm{~S}_{2} 508.17231$, found 508.17183 . 
2. Spectrofluorimetric titrations of compound $\mathbf{2} \mathbf{b}$ with all the tested ions (in acetonitrile)
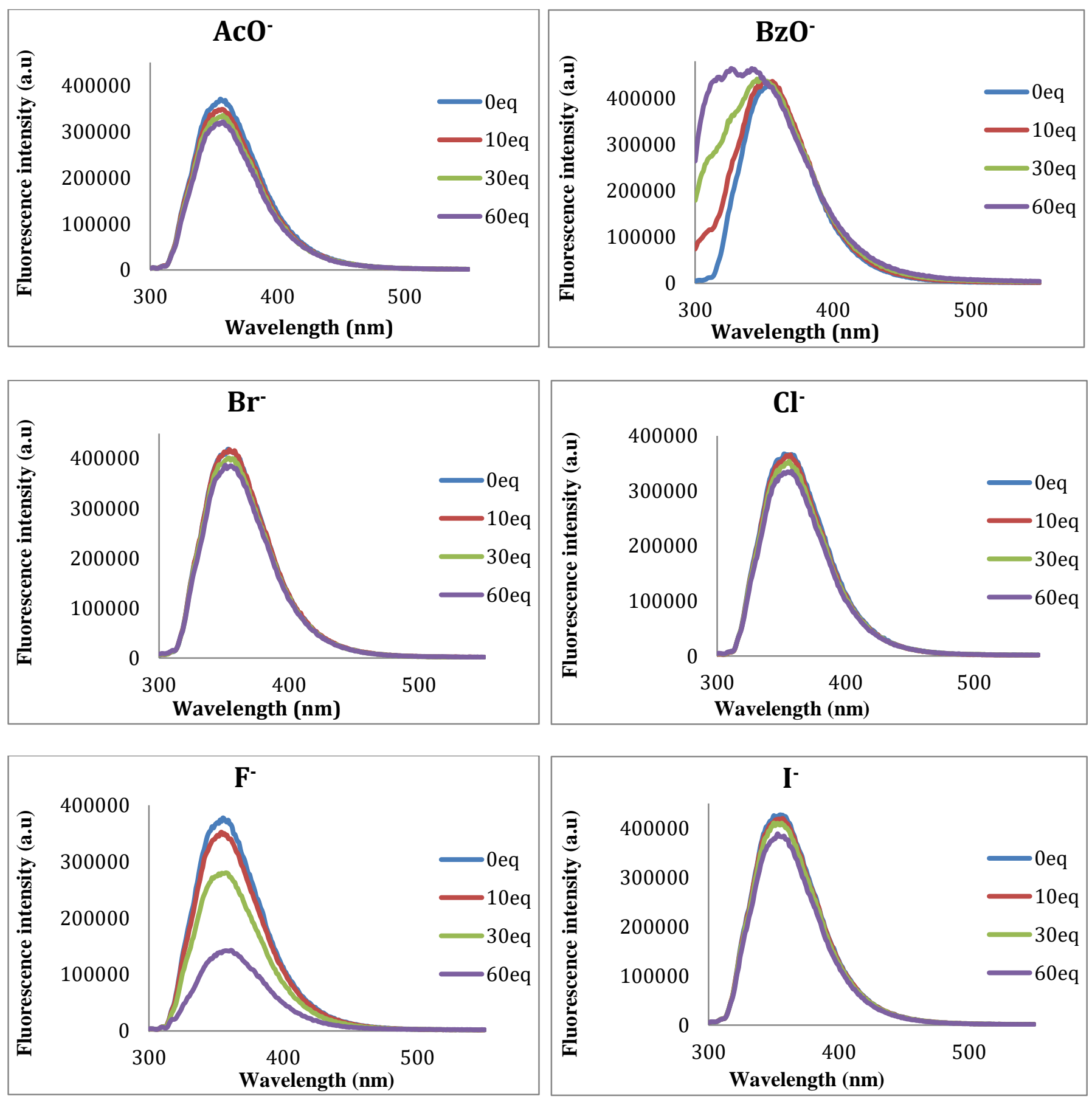

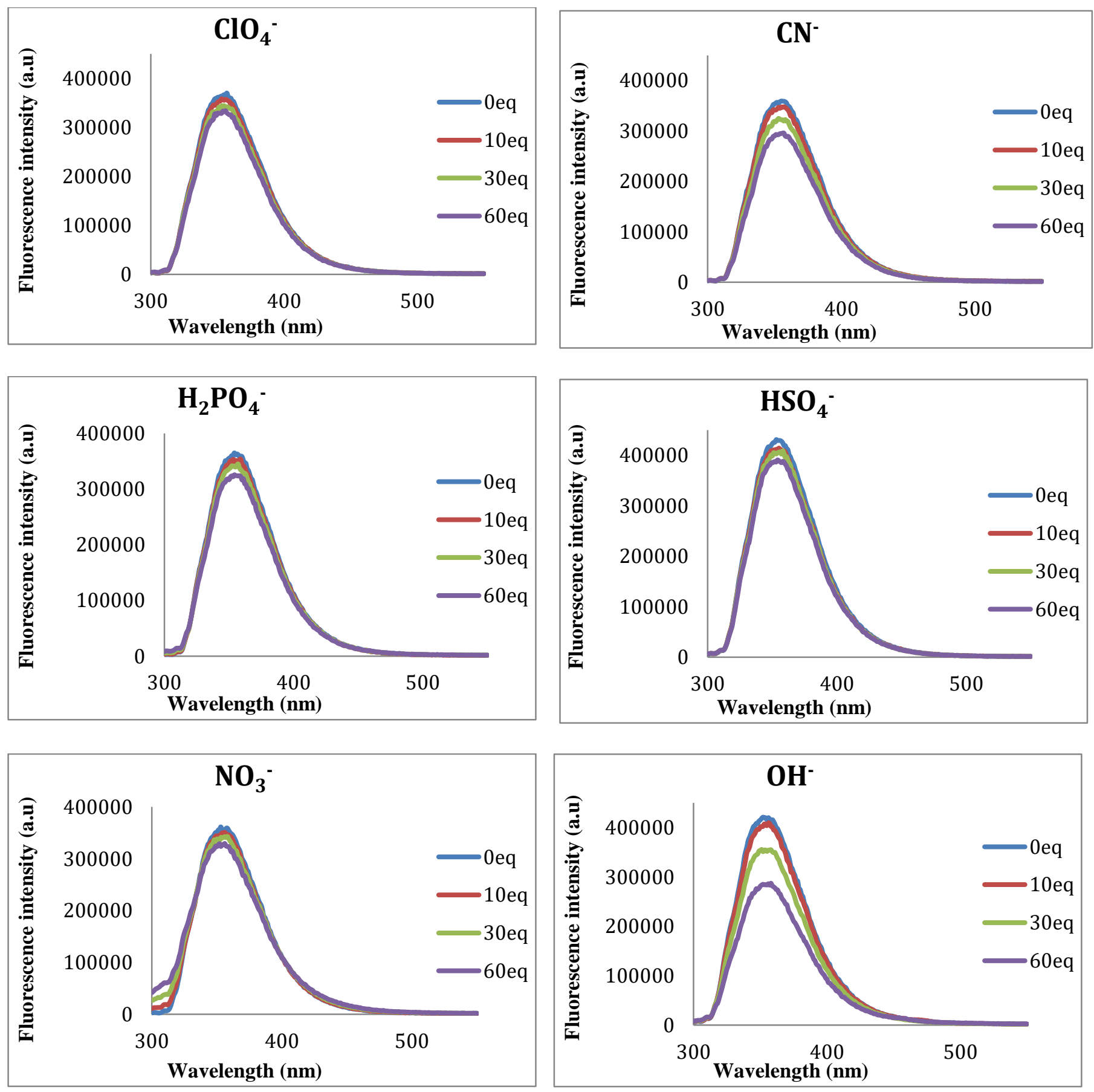

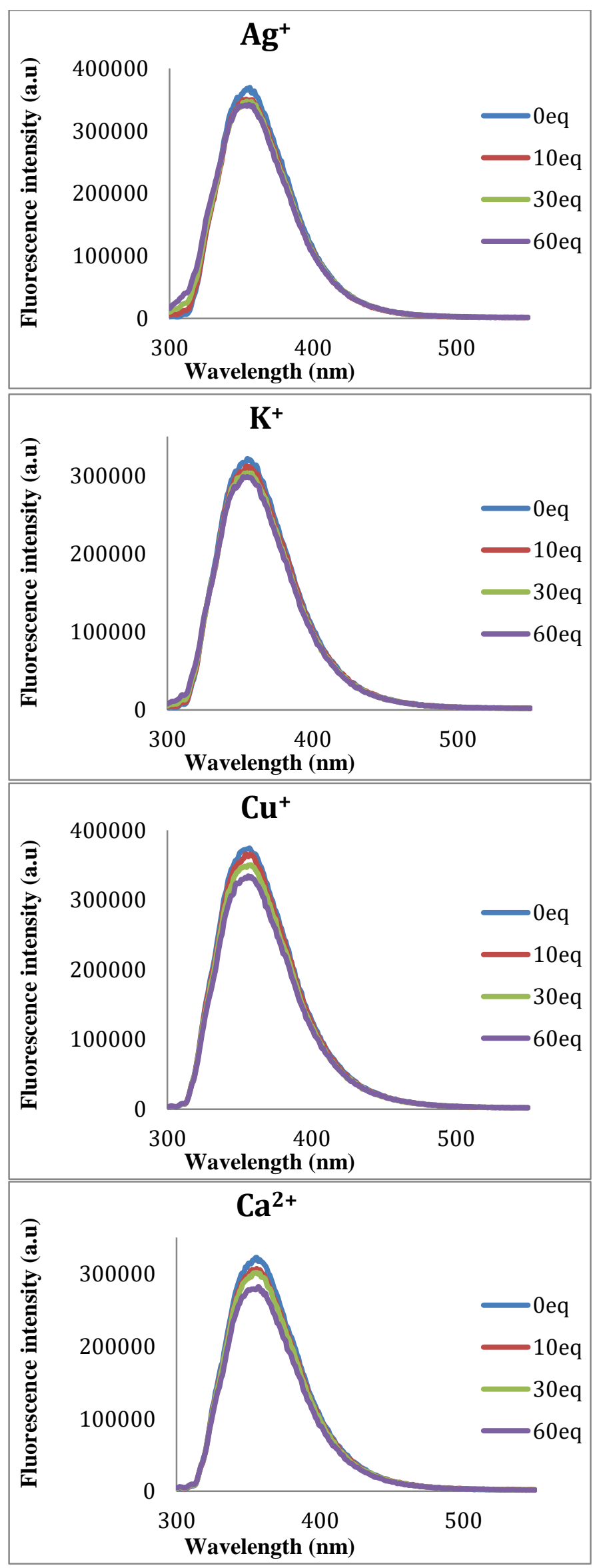
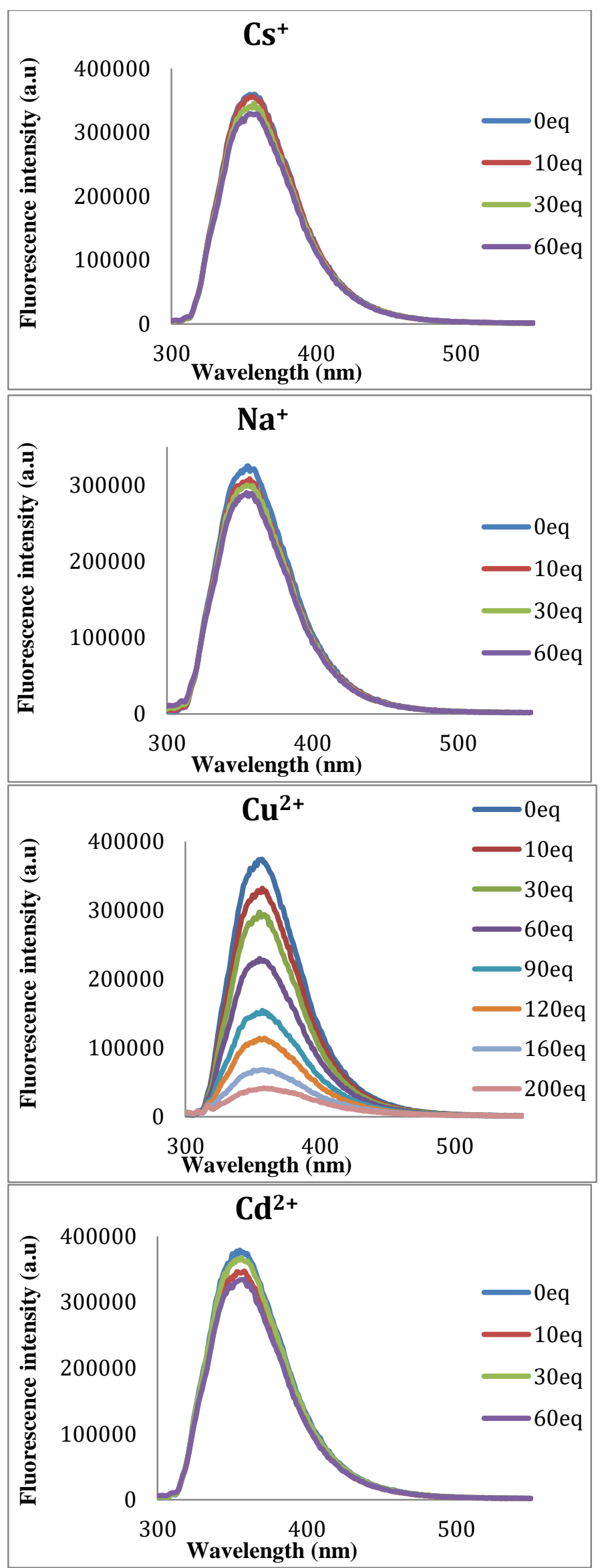

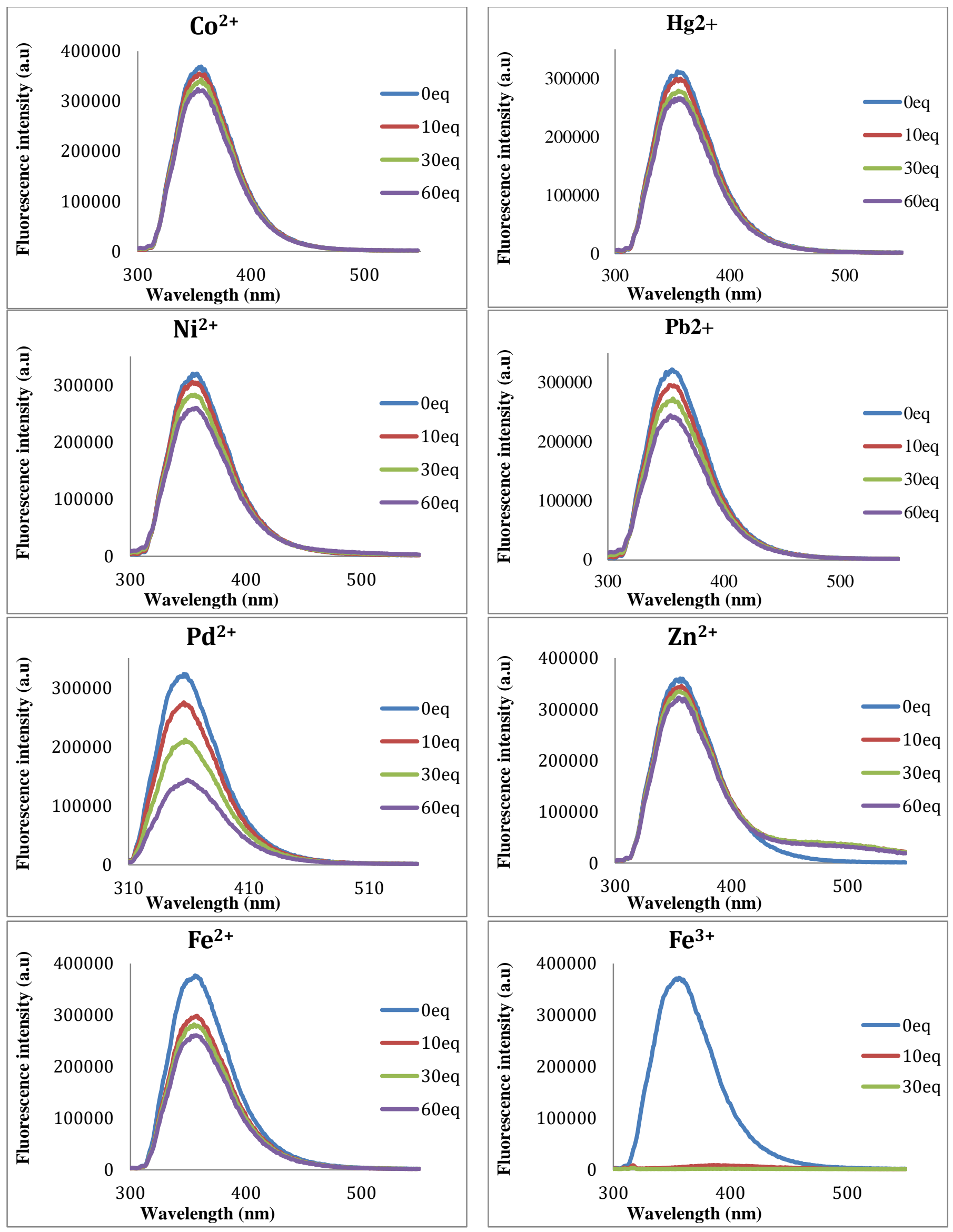


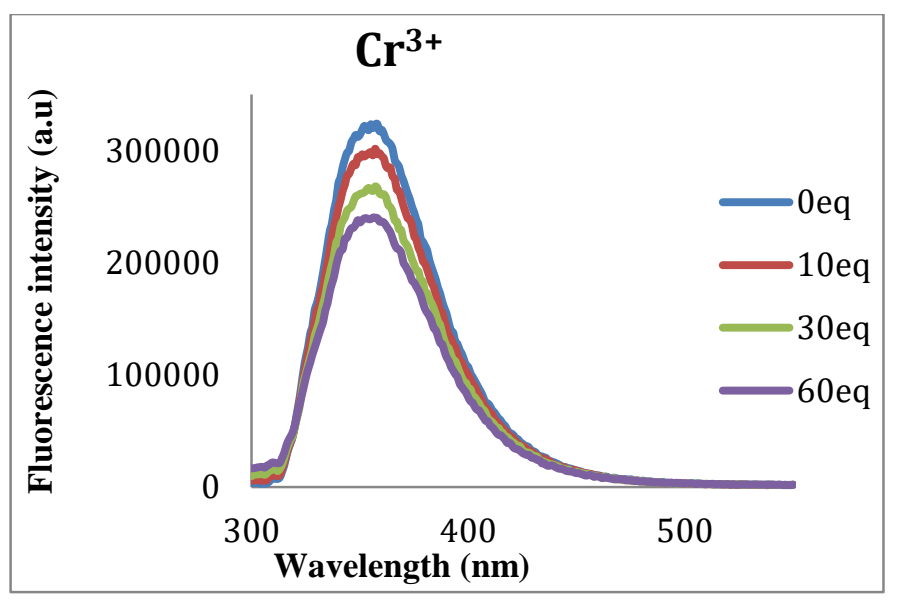

3. Spectrofluorimetric titrations of compound $\mathbf{2 h}$ with all the tested ions (in acetonitrile)
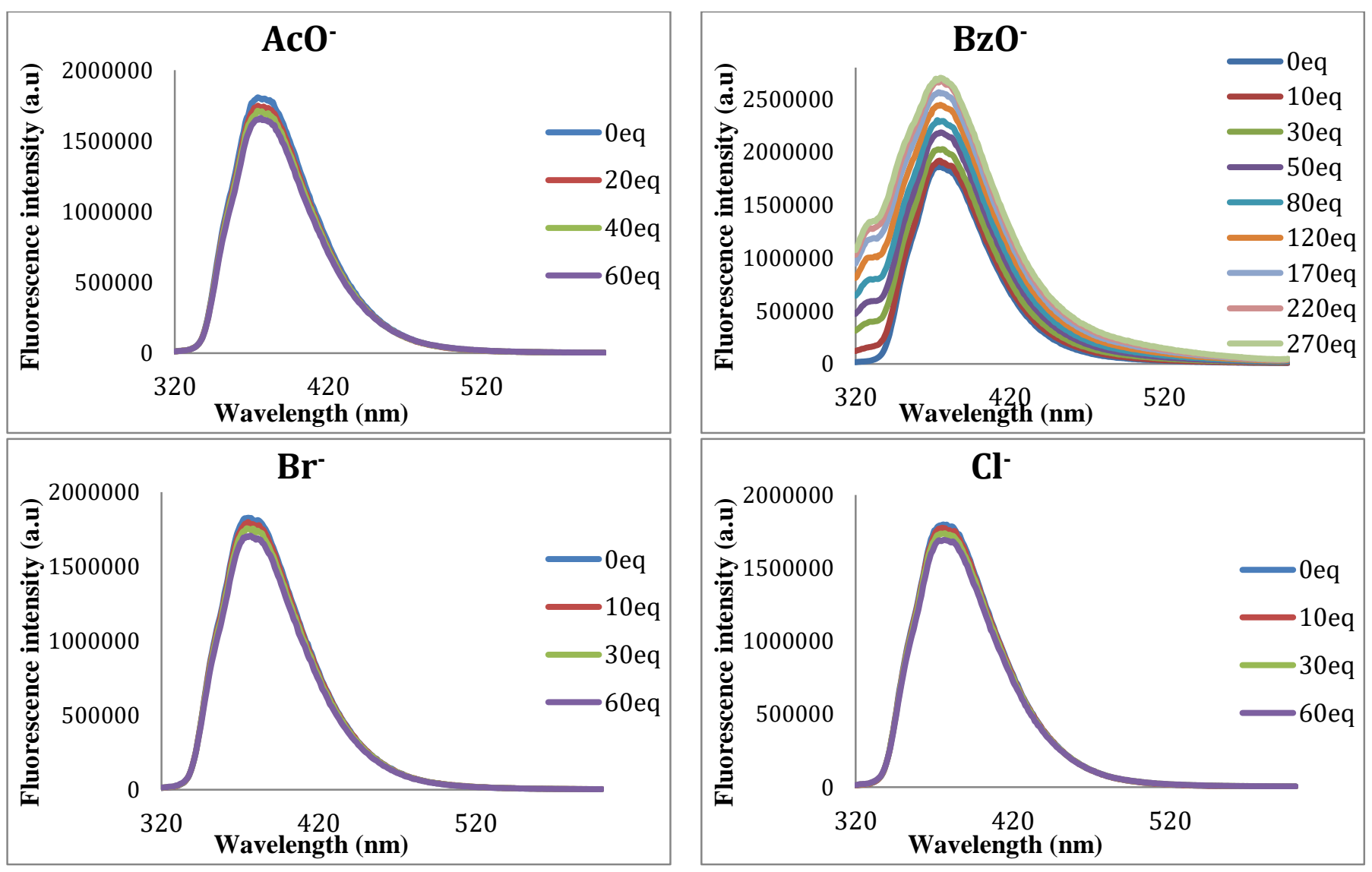

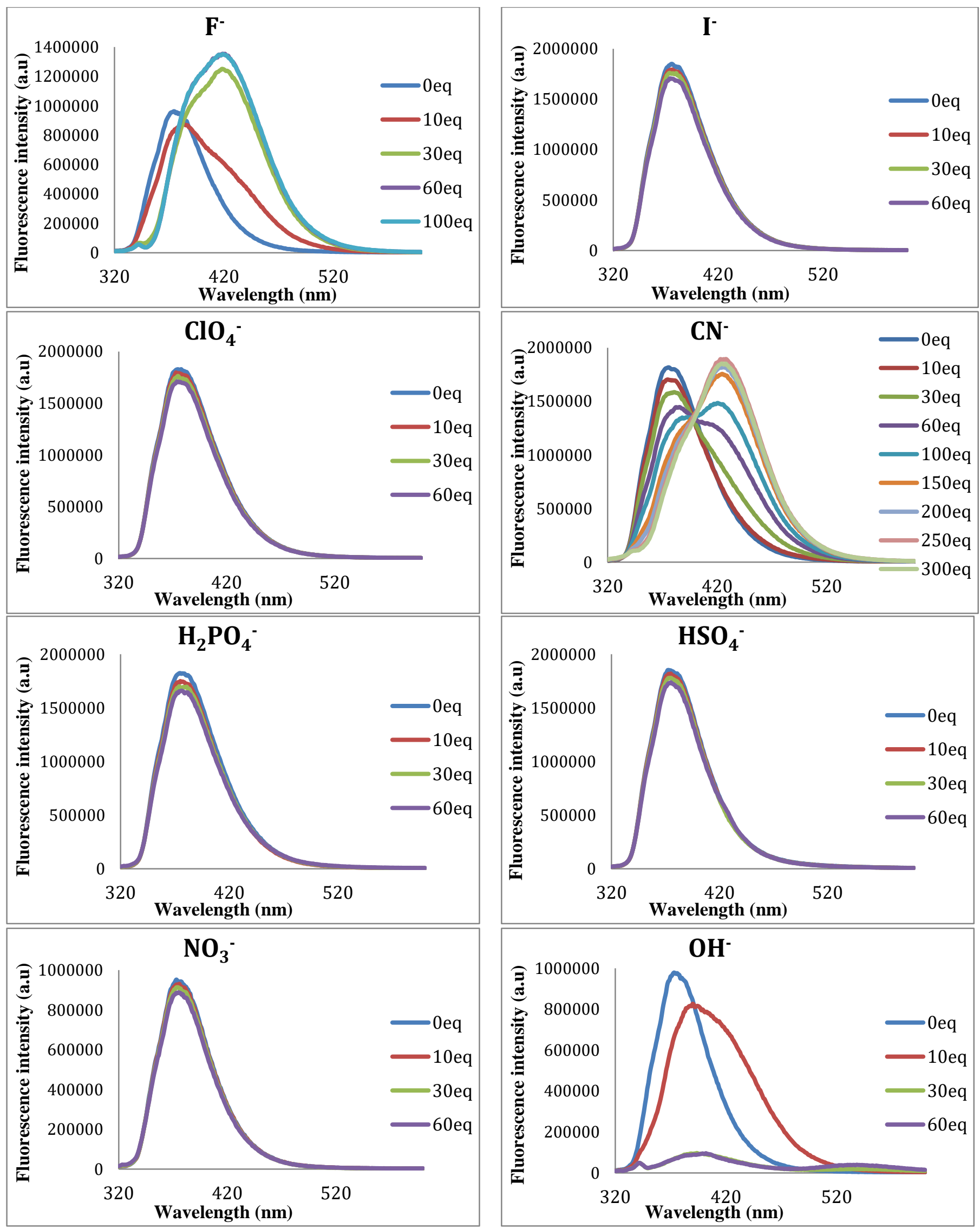

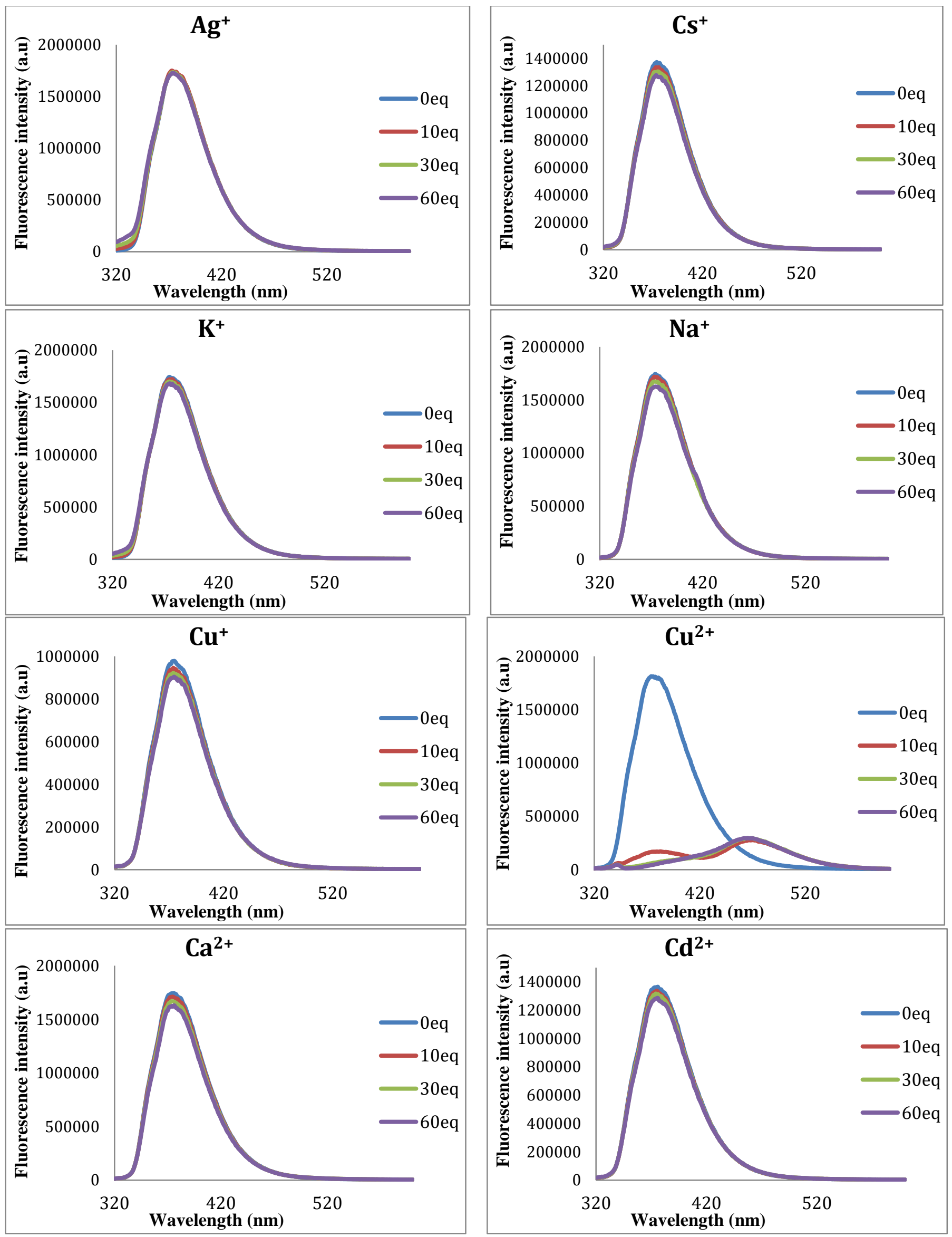

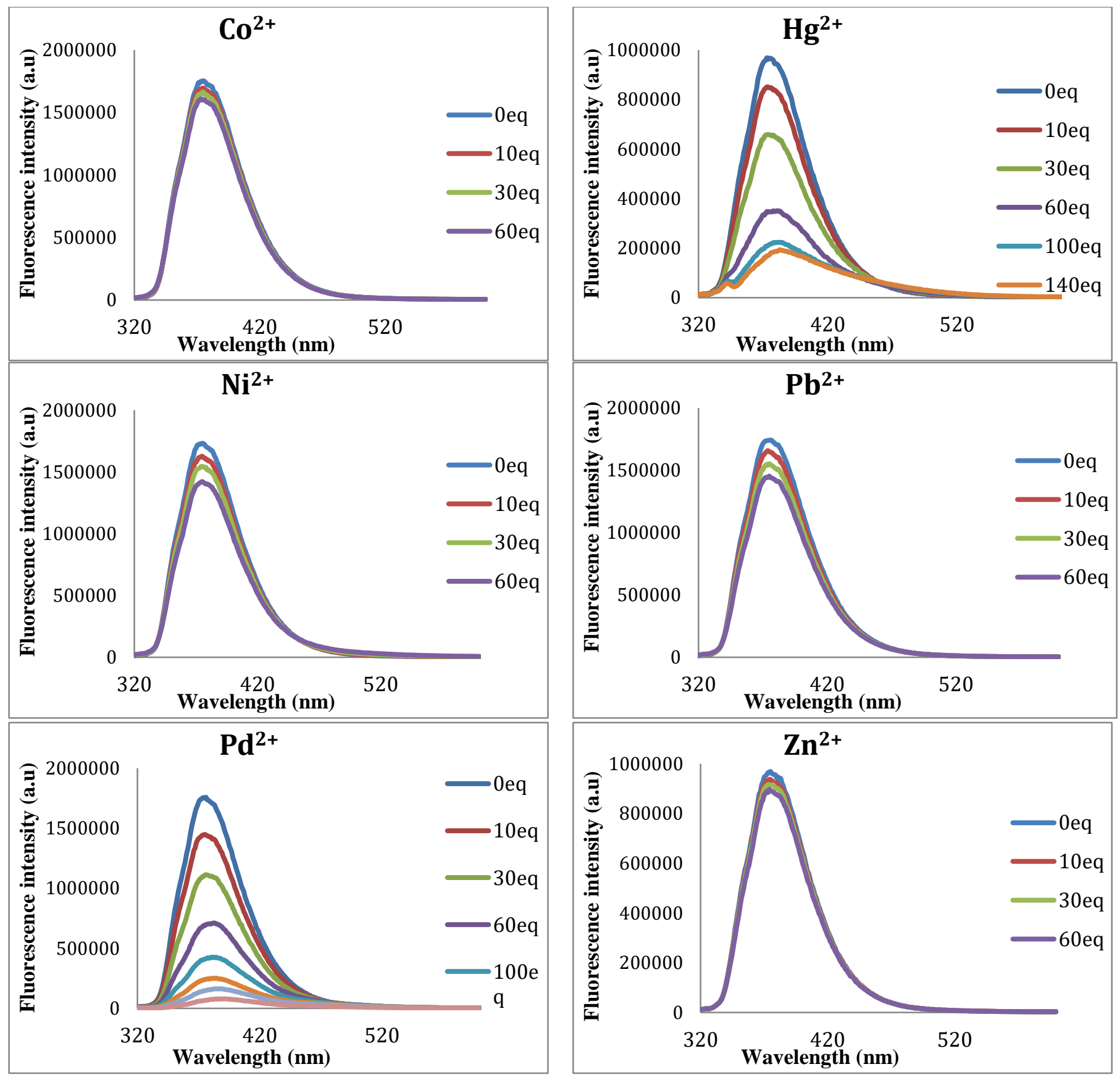

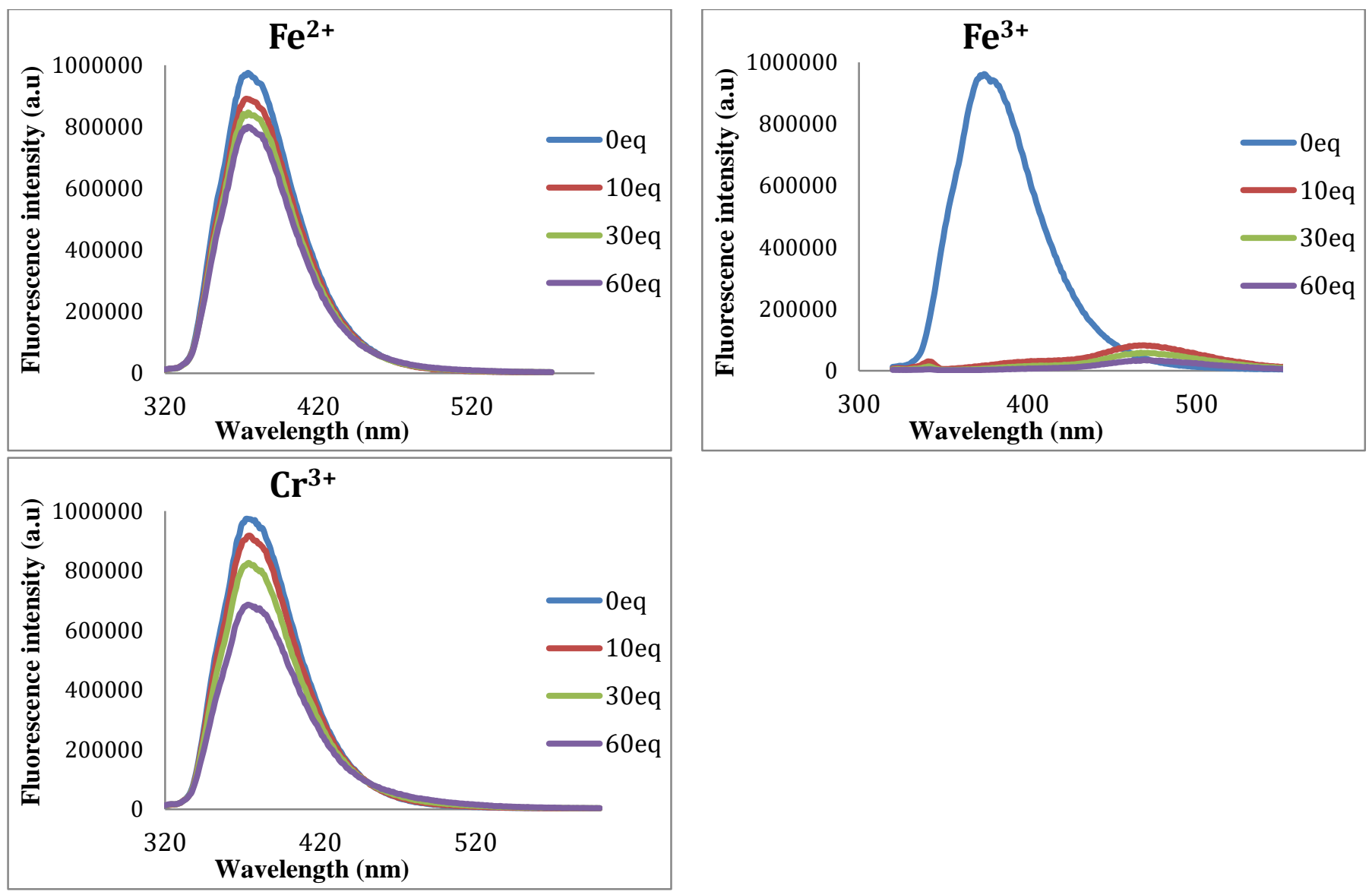

4. Spectrofluorimetric titrations of compounds $2 \mathrm{a}-\mathrm{j}$ with $\mathrm{Fe}^{3+}$ (in acetonitrile)

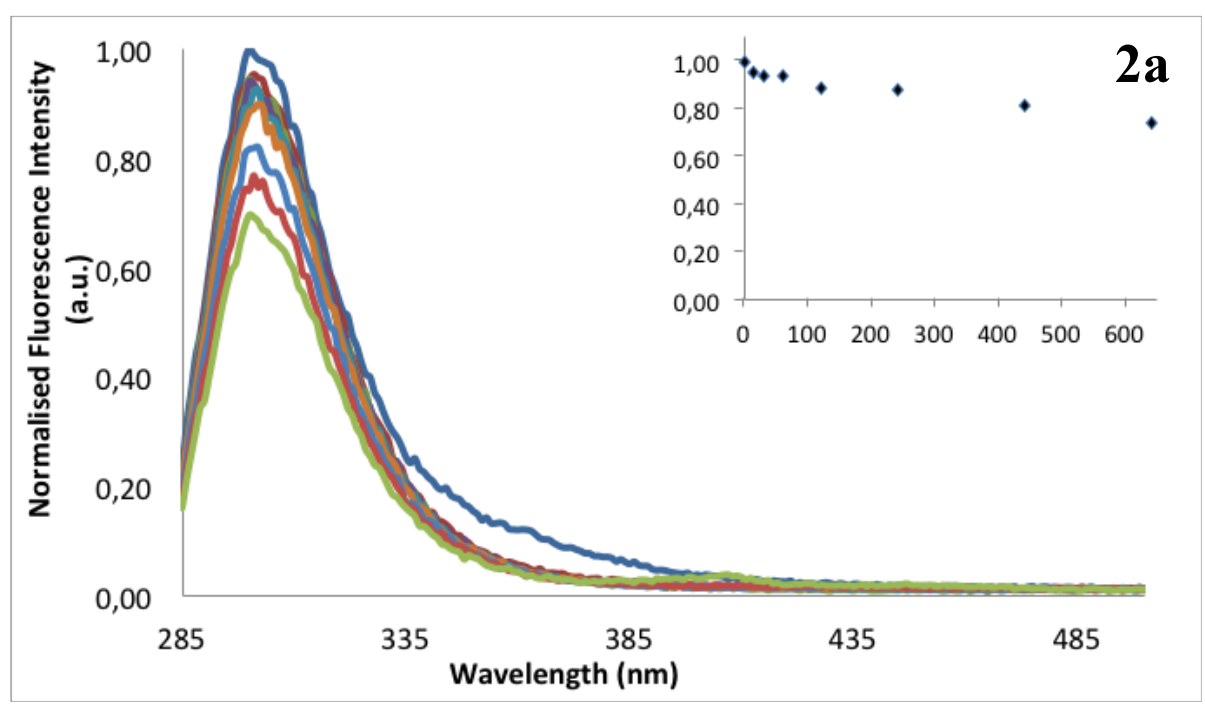



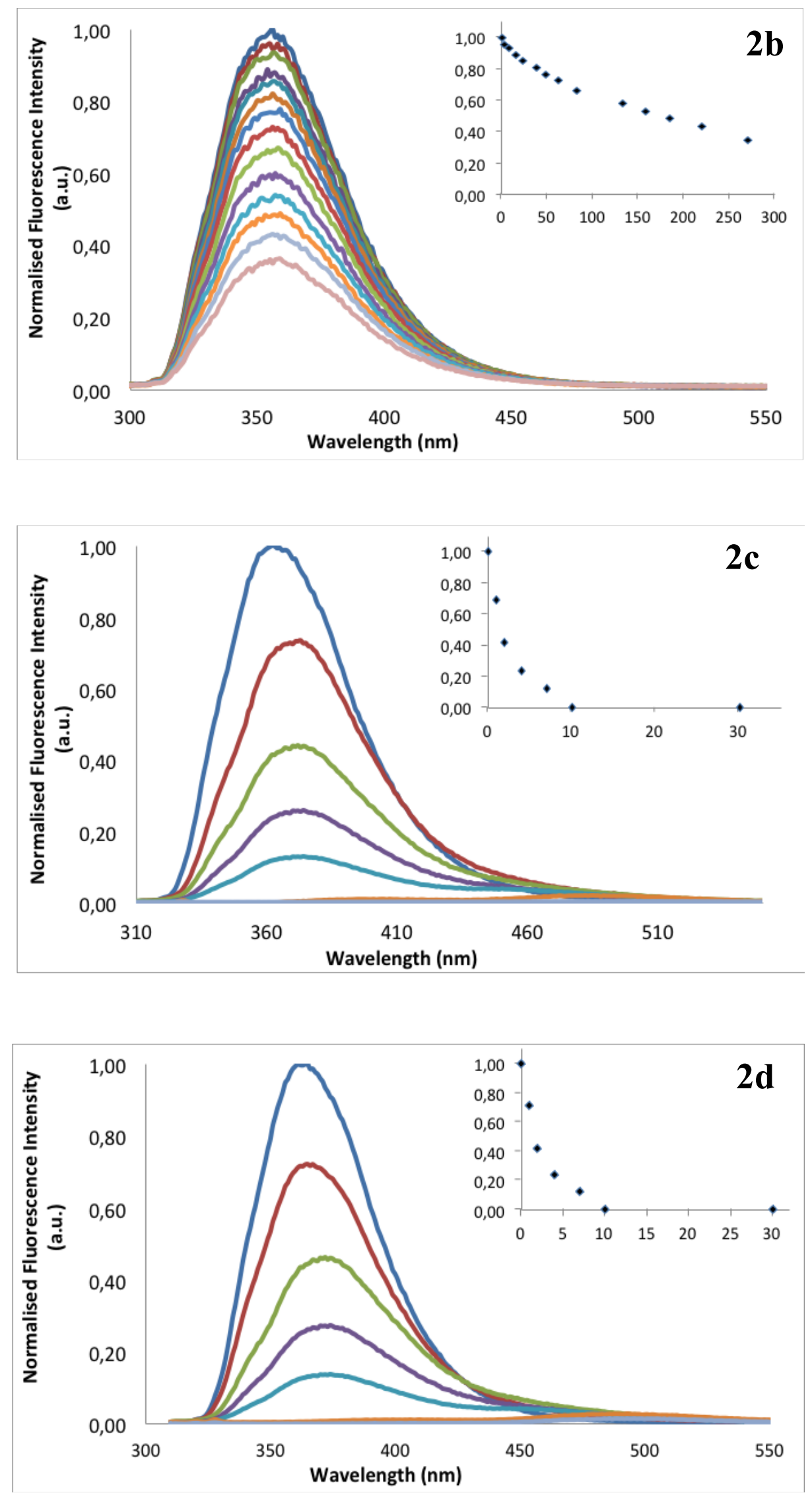

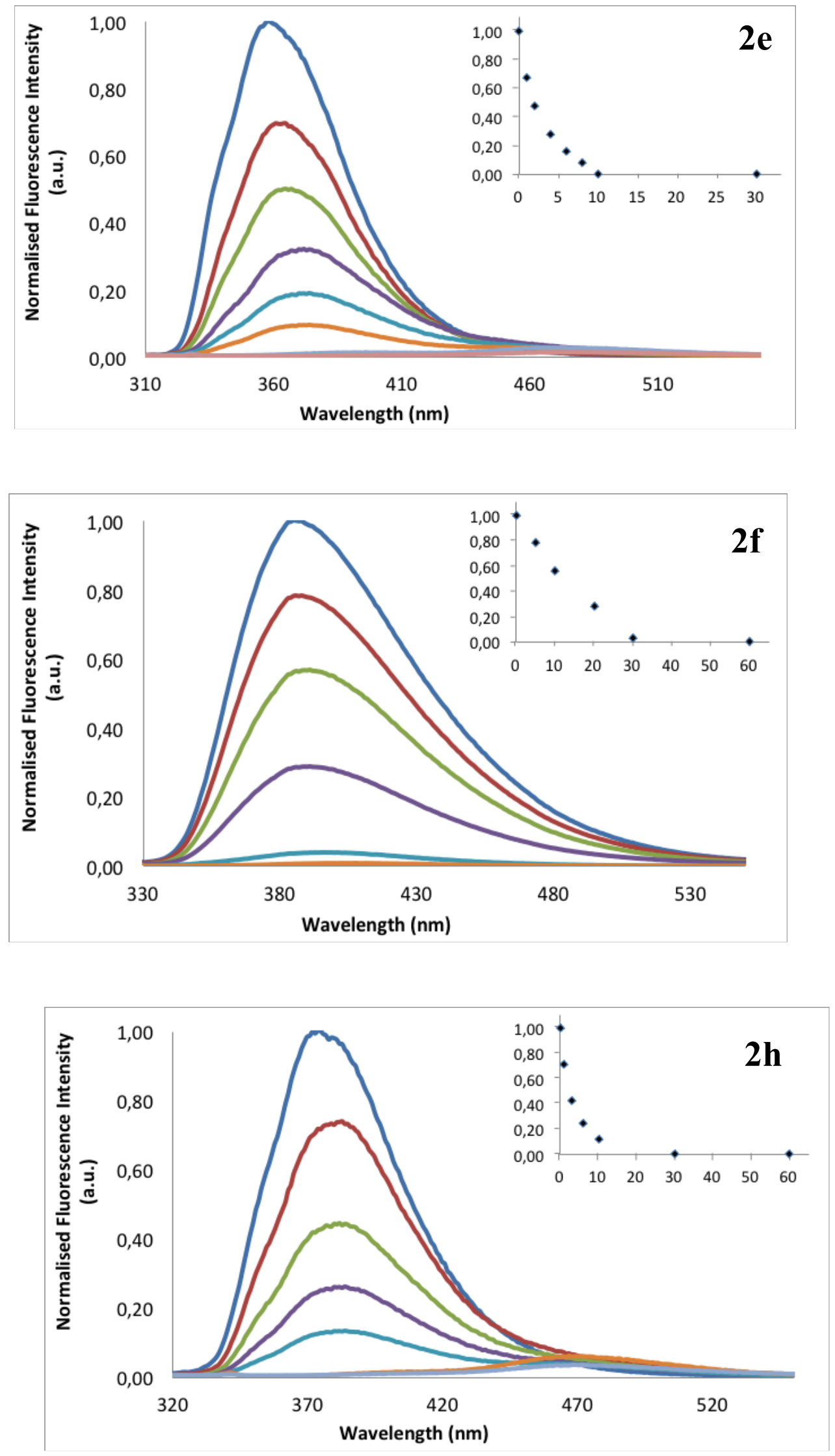


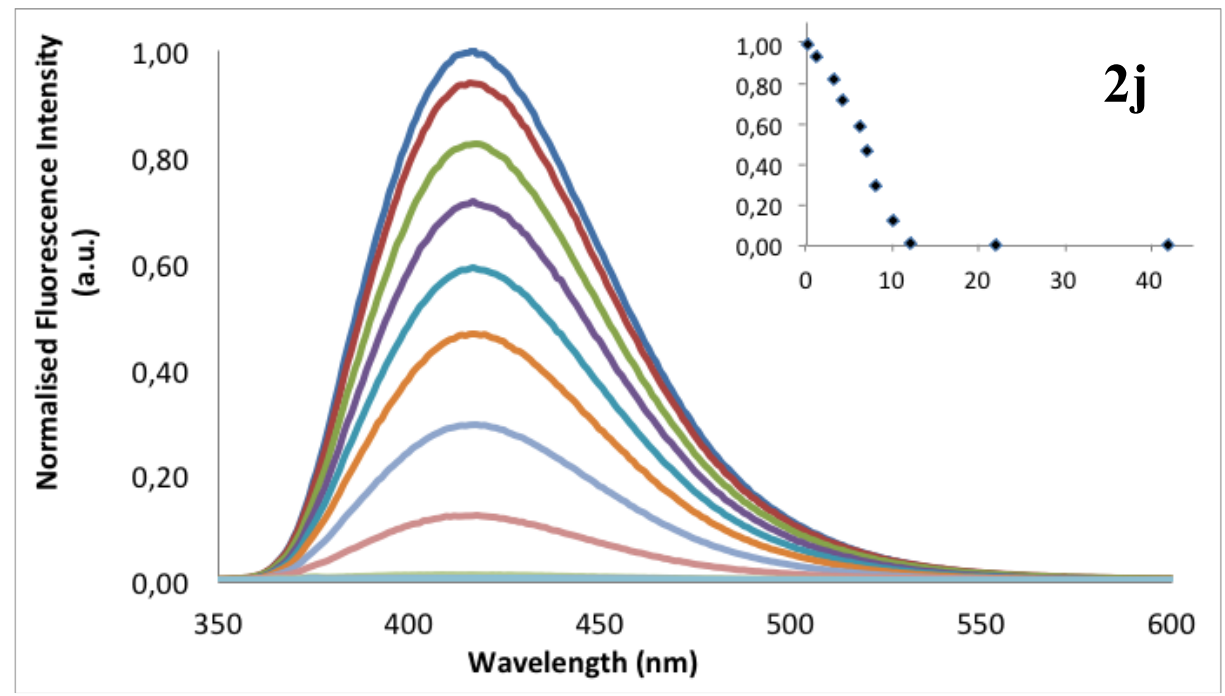

5. Job's plot for compound $2 \mathrm{i}$ with $\mathrm{Cu}^{2+}$ (in acetonitrile)
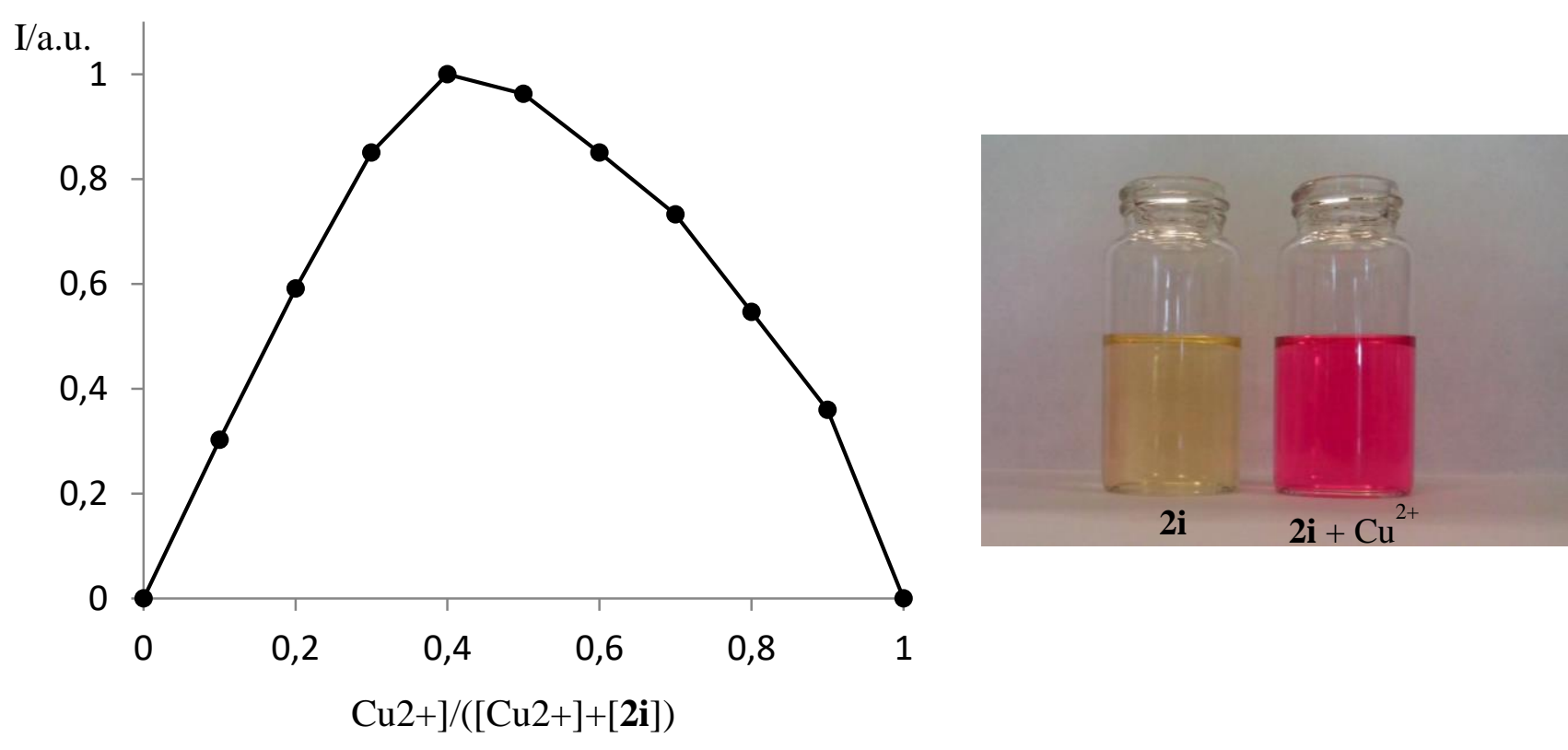